\title{
Misvækst og kornspekulation i Sønderjylland 1698-1847
}

En studie i dyrtids- og hungerår og krisepolitik

\section{Af Lars $N$. Henningsen}

\section{Indledning}

Føde, klæder og varme er menneskets mest fundamentale behov. Ingen kan undvære disse livsfornødenheder, og den enkeltes vilkår er i høj grad afhængige af, på hvilke betingelser han kan erhverve sig det nødvendige. Prisen, som skal betales for de nødvendige forbrugsvarer, er afgørende for levestandarden, og priser varierede i tidligere tider langt kraftigere end $i$ dag. Svingningerne var ofte forårsaget af ydre forhold, især svingende høstudbytte, som mennesker ikke var herre over.

Ikke mindst kornpriserne kunne variere kraftigt, og det påvirkede i datidens primitive landbrugssamfund levestandarden langt kraftigere end $i$ vore dages industrisamfund. I vore dage beslaglægger udgiften til fødevarer kun en ret beskeden brøkdel eller ca. $15 \%$ af en gennemsnitsfamilies budget, og kun ca. $4 \%$ af en husstands samlede udgifter anvendes til indkøb af brød. Forædlede animalske næringsmidler vejer tungest. En sådan forbrugssammensætning er udtryk for en høj levestandard - jo mindre del af forbruget, som optages af levnedsmidler, des højere levestandard.' Den høje levestandard er resultatet af århundreders udvikling. I slutningen af 18 . århundrede må levnedsmidler skønnes at have beslaglagt mindst $70 \%$ af en arbejderfamilies udgifter, og heraf udgjorde vegetabilske produkter (korn) langt hovedparten eller ca. $45 \%$ af samtlige udgifter. ${ }^{2}$ Selv en beskeden stigning i kornpriserne kunne da få vidtrækkende følger. Ofte var lønningerne for de fattigere befolkningsgrupper så ringe, at de selv ved gennemsnitspriser næppe kunne skaffe det nødvendige til livets opretholdelse. Og i bedste fald lagde stigninger hurtigt beslag på den jævne mands fulde købekraft og betød dermed et katastrofalt fald $i$ afsætningen af håndværks- og industriprodukter med depression til følge.

Prisforskydningerne var langt kraftigere og mere bratte, end vi kender det $i$ dag, og årsagen hertil må søges i landbrugets ringe produktivitet. Der var kun beskedne reserver at tære på. Ikke afsætningskriser, men forsyningskriser, vanskeligheder med at skaffe tilstrækkelig mange og tilstrækkelig billige levnedsmidler, var det påtrængende problem. Det gennemsnitlige høstover- 
skud var beskedent, og høstudbyttet kunne let svinge mindst $25 \%$, alt efter hvordan vejret artede sig. Kornmangel og stigende priser, ja sult, hungersnød og stigende dødelighed blev derfor ofte følgen af svigtende høst, og transportmidlerne tillod kun $\mathrm{i}$ begrænset udstrækning transport af en massevare som korn fra områder med overskud til områder præget af mangel. Først ved midten af 1800-årene var landbrugsproduktionen i Europa så rigelig, at man ikke længere behøvede at frygte hungersnød. En stadig voksende kartoffelavl, transportmidler, som tillod import af billigt korn fra oversøiske lande, og et stigende foldudbytte muliggjorde denne gunstige udvikling. ${ }^{3}$

Op til 1846-47 aftegner der sig derimod den ene krise efter den anden med prisstigninger, mangel og stigende dødelighed. Årsager og forløb kunne være forskellige, men kriserne satte normalt deres spor $\mathrm{i}$ hele Europa. Nogle eksempler vil vise det. I begyndelsen af 1570 'erne gik en vældig prisstigning over Europa, fulgt af nød i byerne, som skulle købe varerne, men af rigdom på landet. I 1637/38 rådede hungersnød over hele Tyskland, og i 1690'erne var det atter galt. I 1709 blev en fugtig sommer fulgt af en frygtelig hård vinter - prisstigninger, mangel og hungersnød herskede overalt, og i Frankrig faldt befolkningen, som i 1700 var på 19 mill., til omkring 17 mill. Prisstigning og højere dødelighed gentog sig i 1758-59, og i 1770-72 herskede misvækst, prisstigning og hunger over hele Europa. I land efter land greb man til udførselsforbud, i Preussen blev der anlagt kornmagasiner. I 1785-86 gentog det sig, og hungeroptøjer begyndte at blive mere almindelige. I 1786 og 1788 blev høsten i Frankrig den ringest tænkelige, og sociale vanskeligheder var med til at fremtvinge den store revolution. Resten af århundredet var opfyldt af gentagne "hungerå « «, of te fulgt af uroligheder i den jævne befolkning.

Den sidste alvorlige krise kom i 1845-47, hvor en katastrofal kartoffelmisvækst decimerede den afgrøde, man havde lært at skatte siden prisstigningen $\mathrm{i}$ slutningen af 18. århundrede. Værst gik det $\mathrm{i}$ Irland, hvor underernæring og sygdom halverede befolkningen. ${ }^{4}$

I århundrederne op til 1847 ser man således gang på gang det samme tema spillet igennem i Europas historie. Et sammentræf af uheldige ydre naturforhold skabte mangel og dyrtid med alvorlige sociale følger. Over for disse forhold var alle klasser så at sige i samme båd, underlagt naturens omskiftelser.

Men vi kan ikke standse ved denne konstatering. Menneskene var nemlig ikke blot passive ofre for ydre omskiftelser. De påvirkede selv udviklingen. Over for de udefra kommende svingninger var forskellige klassers interesser ikke altid sammenfaldende. Forbrugeren onskede lave priser, producenten høje, og købmanden, som levede af at omsætte varerne, så en interesse i at 
påvirke udviklingen til egen fordel. Han kunne f.eks. spekulere i stigende kornpriser, kunne udnytte en mangelsituation, og hvis der f.eks. var særlig høje priser på eksportmarkedet, kunne han gøre sit til at blotte hjemmemarkedet for varer med yderligere prisstigning til følge. Derved forværrede han de vanskeligheder, som naturen skabte. Det betyder, at det ikke er tilstrækkeligt at se på naturens luner og høstudbyttet, når man vil belyse prissvingningerne. Spekulanternes rolle må samtidig tages $\mathrm{i}$ betragtning, og staten, som også havde interesser at varetage, påvirkede ligeledes til forskellig tid udviklingen i forskellig retning.

En betragtning af prissvingningerne og deres følgevirkninger er derfor vigtig for at forstå grundlæggende træk og modsætninger i fortidens (og nutidens) samfund. I normale gennemsnitsår kom disse træk ikke så klart til syne - men i kriseår, præget af særlige pludselige prisstigninger, står de lysende klart for iagttageren.

I det følgende vil vi da følge prissvingningerne i udvalgte år i Sønderjyllands historie, og så vidt et begrænset kildemateriale tillader det dristigt vove at få klarhed over nogle fundamentale, men vanskelige spørgsmål: Hvad forårsagede prissvingningerne? Var det misvækst eller kornspekulation? Hvordan påvirkedes de forskellige befolkningsgrupper af prissvingningerne? Hvordan reagerede de over for svingningerne? Hvordan forholdt lokale ovrigheder og staten sig til de skiftende konjunkturer?

Vi vil se, at uheldige klimatiske omstændigheder fra tid til anden skabte misvækst, mangel og prisstigninger. Men handelsspekulation, ofte som en forløber for eller følge af krigsbevægelser, greb afgørende ind i prisforløbet. Spørgsmålet er da: var det $\mathrm{i}$ det enkelte tilfælde misvækst eller købmænds spekulationer i markedet, som skabte den katastrofale mangel og dyrtid, som forbrugerne måtte lide under?

Samtidig vil vi prøve at klargøre, hvordan staten fra krise til krise reagerede forskelligt på de krav om indgreb, som fulgte de akutte prisstigninger. Fra første færd anerkendte staten - og de lokale øvrigheder - det som sin opgave at sikre befolkningen de nødvendigste fornødenheder til rimelige priser. Man ønskede prisstabilitet og tilstrækkelige forsyninger, og det nødvendiggjorde indgreb - ikke mindst eksportforbud i mangelår. En sådan politik var dog ikke altid i overensstemmelse med landbrugets, producenternes eller de handlendes interesser. Fra 1735 gik man derfor $i$ kongeriget Danmark over til en landbrugsvenlig toldpolitik, med forbud mod kornimport og fri eksport - en politik som i kriseår kunne forværre pris- og forsyningsvanskelighederne. I særlig vanskelige år måtte man da også bryde med dette princip og indføre eksportstop og importtilladelser. Endelig voksede fra 1788 frem en liberal, frihandelsvenlig politik, som afviste indgreb 
i handelens frie løb. Det skulle få afgørende betydning i perioder præget af forsyningsvanskeligheder. Hvordan statens rolle skiftede i takt med disse forskellige synspunkter, vil vi også søge belyst $\mathrm{i}$ det følgende.

\section{Kilderne}

Et stort emne med mange facetter søges her skildret over et langt tidsrum for på den måde at illustrere en udviklingslinje. Det betyder, at ikke alle mulige kildetyper og aspekter har kunnet inddrages. Krisernes demografiske følger, tal for høstudbytte, import og eksport og amtsregnskabernes vidnesbyrd er ikke søgt fremdraget. I stedet er en vidt spredt korrespondance i lokale og centrale arkiver udnyttet. Samtidens beretninger og vurderinger af forholdene får her mæle, mens det talmæssige grundlag for vurderingerne kun er inddraget, når det galder prisforløbet. Ud over ufuldstændighed præges kilderne også af nogen skævhed. Det er forbrugerinteresserne, ikke producenter og handlende, det er kort sagt de klagende parter, som taler gennem kilderne. Men forhåbentlig er det trods disse mangler alligevel lykkedes på forsvarlig måde at pege på væsentlige og holdbare udviklingslinjer.

\section{8-99}

Problemer vedrørende kornforsyning, prissvingninger og spekulationsopkøb har eksisteret til enhver tid. Vi møder dem, så snart kilderne i 16. årh. begynder at tale. Et par eksempler: I 1543-44 måtte korneksport forbydes og import organiseres på grund af dyrtid og mangel; i 1570'erne hører vi gentagne gange om misvækst, kornmangel og spekulationsopkøb af korn; i slutningen af 1590'erne tordnede sognepræsten i Hellevad-Egvad Niels Heldvad mod købmænd, storbønder og møllere, som udnyttede dyrtiden til egen fordel, ${ }^{5}$ og i 1675 høres om lignende problemer. ${ }^{6}$

Først i 1698-99 begynder de lokale kilder dog at flyde mere rigeligt, og her tager vi da vort udgangspunkt. Fra første færd ses, hvordan de alvorligste problemer opstod som følge af et samspil mellem naturens omskiftelser og menneskers indgriben. Vi vil også se, at forholdene i Sønderjylland til enhver tid var en brik $i$ en almen europæisk sammenhæng.

Årene 1698 og 1699 hørte i hele Europa til de værste misvækstår i det 17. århundrede. Kulde i foråret 1698 truede vintersæden, og stærk regn ødelagde årets høst i Østeuropa, Europas kornkammer. Priserne galopperede opad om vinteren 1698/99, og land efter land greb til kornspærring for at beskytte hjemmemarkedet. Rundt om kom det til hungeroptøjer, der blev oprettet kornmagasiner, og sørget for billigt korn til ubemidlede. ${ }^{7}$ 
I Sønderjylland viste de første problemer sig i foråret 1698. I februar blev der klaget over en kraftig udførsel af tørv. Prisen steg, og i Tønning og Frederiksstad var tørv næsten ikke til at skaffe. Derfor forbød den gottorpske hertug d. 19. februar al udførsel af tørv. ${ }^{8}$

Høsten førte ikke til et prisfald. Den slog fejl, og kornmarkedet blev stramt. Tilførslen fra Danzig, Preussen og Livland ophørte på grund af udførselsforbud, og kraftig udførsel fra Sønderjylland og stort forbrug i brændevinsbrændingen skabte mangel og prisstigning på hjemmemarkedet. Klagerne lød højlydt, og d. 17. september forbød hertugen derfor al brændevinsbrænding. Samtidig skulle de lokale øvrigheder forhindre, at der blev udført så meget korn fra det enkelte amt, at de hjemlige behov ikke kunne opfyldes.' I kongeriget blev udførsel af rug og hvede, også til hertugdømmerne, forbudt samme dag for at modvirke dyrtid, ${ }^{10}$ og tre uger senere fulgte kongen hertugens eksempel med et tilsvarende forbud mod brændevinsbrænding og udførsel fra de kongelige områder af Sønderjylland. ${ }^{11}$

Standsningen af kornudførslen fra kongeriget ogede forsyningsproblemerne i hertugdømmerne, især i byerne. Flensborg klagede over stor mangel, ikke mindst på grund af brændevinsbrændernes forbrug og fremhævede, at man ikke kunne klare sig uden den normale tilførsel fra kongeriget. Derfor dispenserede Frederik 4. d. 1. november fra udførselsforbudet og tillod, at de kongelige byer Flensborg, Haderslev og Sønderborg kunne importere 500 td. rug og 500 td. hvede fra Lolland og Falster. ${ }^{12}$

På landet kneb det at skaffe den nødvendige sæderug, og undersåtter $\mathrm{i}$ Haderslev amt fik derfor tilladelse til at indføre sæderug fra Fyn. ${ }^{13}$

I Sønderborg amt tyngedes bønderne så stærkt af dyrtiden, at amtsforvalter Samlandt måtte vise overbærenhed ved inddrivelsen af de kongelige skatter. $^{14}$

Endnu et bevis på mangelsituationen møder vi i Sønderborg, hvor de menige borgere som led i kampen mod det rådende købmandsoligarki krævede, at udskibningen blev standset, og at de store kornhandlere skulle holde korn tilbage $i$ et slags magasin til salg for billig pris til de mindrebemidlede. ${ }^{15} \mathrm{Her}$ antydes et motiv, som vi vil se spillet igennem gang på gang gennem de næste 150 år: modsætningen mellem kornhandlerne og producenterne, som ønskede den størst mulige og mest givtige eksport, og den menige forbruger, som led under høje priser og stærk eksport.

Modsætningen kan illustreres med mange eksempler. Bønderne i vigtige kornproduktionsom råder som Sydditmarsken, Krempe- og Wilstermarsken ønskede naturligt nok fri udførsel og anførte, at de ikke kunne sælge overskudsproduktionen på hjemmemarkedet. Følgen for dem blev svigtende 
indtægter og dermed forringet mulighed for at betale de kongelige skatter. Regeringen var her i en klemme, og i 1698 tillod den derfor, at byg kunne udføres fra marsken, når blot byerne på forhånd blev sikret de nødvendige tilførsler. ${ }^{16}$

Det følgende år 1699 ser vi mønstret gentaget. Fra fastelavn 1698 til fastelavn 1699 fordobledes rugprisen i Bramstedt i Holsten fra $7 \mathrm{mk} .10$ skl. til 14 mk. 10 skl. pr. td. ${ }^{17}$ I juni måned tydede meget tynde rugmarker på en dårlig høst, og priserne var fortsat uhørt høje. Tilførsler fra Østersøen ophørte, og udførslen kunne ikke hindres. Flensborg klagede over, at fremmede købmænd købte rug op i landsbyerne og førte det til vestkysten med det resultat, at mangelen øgedes, og at rug på knap en måned steg fra 12-13 skl. pr. skæppe til 20-24 skl. Bagere og brændevinsbrændere kom i en alvorlig knibe, og magistraten frygtede virkelig nød, hvis udførslen vedblev og den manglende tilførsel af rug til byen fortsatte. ${ }^{18}$ Også fra Haderslev lød der i sept. klager over rugmangel og nogen tid efter klagede Frederiksstad på samme måde over svigtende tilførsel og en prisstigning, som truede de fattiges, for ikke at tale om bryggeres og brænderes eksistens. ${ }^{19}$ Flere steder måtte almuen tage til takke med brød af byg og boghvede blandet med hø og lyngfrø. $^{20}$

De mange klager over mangel og prisstigning fremkaldte en forlængelse af udførselsforbuddet fra såvel kongens som hertugens side, ja der måtte end ikke føres korn fra et amt til et andet. Hensigten var ikke mindst at lette korntilførslen til byerne. ${ }^{21}$

Men da udførsel fra Danmark til Sønderjylland også var forbudt, hjalp det ikke meget. Flensborg klagede gang på gang over, at der ikke var tilførsel at få fra landet og ikke fra Østersøen, og at byen, bryggerne og befolkningen i almindelighed blev sat $i$ en håbløs situation, såfremt der ikke kom korn fra kongeriget. ${ }^{22}$ Oven i købet forlød det stadig, at udførsel hemmeligt fortsatte trods forbud.

Dette var forbrugernes stemme. Fra marsken blev regeringen atter bestormet med klager over, at bønderne ikke kunne komme af med kornet. Marskbønderne hævdede, at byerne ventede med at købe $\mathrm{i}$ håb om prisfald, og at de søgte at presse landmandens priser ned. Derved kom statens skatteindtægter i fare. Regeringen lod sig påvirke og pålagde følgelig byerne at fremme de nødvendig indkøb, men det skulle ske $i$ hertugdømmerne; fra Danmark skulle de ikke vente at få adgang til billige indkøb. ${ }^{23}$

Konkluderende må fremhæves, at årene 1698-99 har været præget af betydelige vanskeligheder med hensyn til kornforsyningen. Høsten slog fejl to àr i træk, og sammen med standsning af forsyninger fra udlandet og illegal eksport til givtige priser skabte det alvorlige mangelforhold $\mathrm{i}$ byerne, og vel 
også for nogle på landet. Midlerne herimod var eksportforbud, men regeringen søgte samtidig at tage skyldigt hensyn til producenternes interesser. Desuden møder vi de første eksempler på, at man indførte særlige kreditordninger til sikring af bøndernes indkøb af manglende sædekorn. ${ }^{24}$ Det dårlige høstudbytte var hovedproblemet, men i baggrunden lurede den stærke efterspørgsel fra udlandet som en spore for købmændene til illegal eksport, en eksport som var en alvorlig trussel mod den hjemlige forbruger.

\section{$1708-1710$}

I de følgende år fra 1701 til 1707 faldt priserne til ro i et meget lavt leje som udtryk for en gunstig forsyningssituation. Men de gode tider for forbrugerne fik en ende. Årene 1708-10 blev hjemsøgt af så mange ubehageligheder, at de blev husket gennem generationer. Sommeren 1708 blev kold og fugtig, og efteråret var præget af kraftige regnskyl. Vinteren blev ekstrem hård. Lissabons havn blev lukket af isen, i Venezia frøs kanalerne til, Provences olivenskove blev ødelagt, man kunne køre i slæde på isen fra København til Bornholm og fra København til Haderslev i karosse med 4-spand. I Åstrup præstegård frøs vin, brændevin og spiritus til is. Den hårde vinter skabte overalt misvækst og dyrtid i 1709. En stribe af korneksportforbud blev indført, kornmagasiner oprettedes, og eksempelvis steg priserne i England med $200 \%$. Især Frankrig, som samtidig var indviklet i Den spanske Arvefølgekrig, blev hårdt ramt. De allierede stoppede som led $\mathrm{i}$ krigsførelsen alle tilførsler, og en katastrofal hungersnød bredte sig. Ludvig 14. søgte overalt at opkøbe korn for at lindre nøden, og kornhandlere kunne sælge alt, hvad de kunne skrabe sammen til dobbelt så høj pris som året før. Dødeligheden steg til uanede højder. ${ }^{25}$

I Danmark steg priserne brat, vintersæden blev ødelagt, såsæd blev en mangelvare, og mange fattige i Jylland døde af hunger og tørst. ${ }^{26}$

Hvordan klarede Sønderjylland sig gennem denne krisetid? Allerede sidst på året 1708 var problemerne akutte rundt om. Krigsforholdene stimulerede sandsynligvis en betydelig kornudførsel, og i Sønderborg føltes mangelen hårdt hen mod jul 1708. Til skade for den menige mand blev korn købt op og for vindings skyld holdt tilbage. Priserne steg, og det gik ud over småfolk. Guvernøren Ernst August truede ved juletid kornhandlerne med straf, hvis de ikke sørgede for at borgerne fik korn, der ikke var for dyrt. Borgmester og råd bekendtgjorde samtidig, at man ville hjælpe indbyggere, som forgæves havde søgt at købe korn hos kornhandlere, til det nødvendige korn. Kornhandlerne fik pålæg om ikke at nægte salg til nogen betalingsdygtig kunde. $^{24}$ 
I 1709, efter den ekstremt hårde kulde $\mathrm{i}$ januar og februar måned, tog vanskelighederne til. I Amsterdam kunne korn sælges til den dobbelte pris af året før, og i Slesvig og Holsten fik kornudførsel og brændevinsbrænding priserne til at stige. Mangelen tog til. I Åbenrå måtte magistraten udstede nye regler for bagernes brødbagning, ${ }^{28}$ og i maj og juni måned lod både hertugen på Gottorp og den danske konge brændevinsbrænding og korneksport forbyde. Brændevinsbrænderne blev tvunget til at aflevere deres grej på rådhusene. Kongen bestemte endvidere, at korn ikke måtte udføres fra de kongelige dele af hertugdømmerne til de gottorpske, "fordi dyrtid og mangel kunne forårsages derved . $^{29}$

En kort overgang i ftersommeren syntes det, som om det værste var drevet over, og der blev atter i begrænset omfang åbnet for kornudførsel, men i oktober steg priserne atter, da det blev klart, at høsten var slået fejl; særlige indgreb blev nødvendige for at sørge for de ubemidlede. D. 5. okt. 1709 greb hertug Christian August på Gottorp da til et bemærkelsesværdigt middel. For at komme undersåtterne og især de fattige til hjælp befalede han byerne $i$ sit hertugdømme, altså bl. a. Åbenrå og Tønder, at indrette kornmagasiner. På byernes bekostning skulle rug og byg til i alt et års forbrug indkøbes, og de borgere, som havde oplagsrum, var forpligtet til at opbevare dette sikkerhedslager. Kornopkøbet kunne evt. finansieres ved lån hos de mere velhavende borgere. Forrådet skulle fordeles til befolkningen $\mathrm{i}$ forhold til deres økonomiske kår. De velhavende kunne købe til indkøbsprisen, mellemklassen til moderat pris, og de helt ubemidlede skulle have korn gratis. ${ }^{30}$ På denne måde søgte statsmagten at modvirke følgerne for de fattige af alt for voldsomme prisstigninger, og den pålagde den enkelte bykommune at sørge for sine egne fattige. I samme ånd havde den gottorpske regering allerede d. 6. nov. 1708 pålagt magistraten i Åbenrà at udarbejde en plan for forsørgelsen af byens fattige. ${ }^{31}$

På landet var der også vanskeligheder. I Åbenrå amt var der misvækst og mangel på rug til brød. Mange måtte bruge byg og boghvede i stedet, og Hellevad mølle klagede over den ringe omsætning. ${ }^{32}$ Fra Tønder amt beretter pastor Niels Ewald i sin kirkebog om året 1709: „I dette år har der også været en sådan misvækst på den kære rug, at sæderug $\mathrm{i}$ almindelighed kostede 7-8 rdl., ligesom 1599. Nogle fik $10 \mathrm{rdl} .$, nogle mere, nogle mindre. Dog blev derfor på de fleste steder meget land ikke tilsået. Denne misvækst har ikke alle steder været lige slem, men har ramt nogle sogne og landsbyer mere end andre, ja har i nogle landsbyer ramt nogle agre mere end andre. J eg for min person kan ikke nok takke Gud for hans rige velsignelse på mine agre mod de andres."

Som antydet skabte den dårlige rughøst mangel på sæderug, og en 
mangelfuld såning indebar risiko for endnu en dårlig høst. Det var et faretruende perspektiv. Derfor pålagde regeringen kort efter høstens afslutning samtlige amtmænd at drage omsorg for, at markerne blev tilsået og sørge for kredit til de bønder, som havde brug for at låne sæderug. ${ }^{33}$

Selv om kilderne er sparsomme, er der herefter næppe tvivl om, at årene 1708-09 var kritiske - kulde og regn skabte misvækst og dyrtid, og krigsforhold, priseksplosion og mangel $i$ især Holland og Frankrig stimulerede udførslen, med øgede vanskeligheder herhjemme til følge. Øvrigheden greb ind og erkendte en forpligtelse til at regulere. Den indførte forbud mod eksport og brændevinsbrænding, og krævede oprettelse af kornmagasiner. Først i 1711 faldt priserne atter til et rimeligt leje.

\section{$1740-41$}

Efter de voldsomme prisstigninger 1708-10 gik priskurven ind $i$ et faldende forløb indtil slutningen af 1730'erne. Afsætningen svigtede, og landbrugerne led under den ringere indtjening, mens forbrugerne til gengæld havde gavn af prisfaldet.

I årene 1740-41 blev den nedadgående bevægelse brat afbrudt. Samspil af en lang række uheldige faktorer gjorde disse år til de værste kriseår siden 1709. De første varsler om begyndende vanskeligheder viste sig i januarfebruar måned 1740. D. 29. januar om aftenen så pastor Monrad i Åstrup et stort lys på himmelen. Det gik fra nord til syd og varslede stærk frost. I ind-og udland sprang termometrene af kulde, mange mennesker spadserede over isen fra Sjælland til Skåne. Kulden blev $8-9^{\circ}$ værre end i $1709 .{ }^{34} \mathrm{~N}$ d og elendighed bredte sig. Transporten gik i stå, folk hundefrøs med enormt stigende brændselspriser, tiggeriet tog til. Priserne steg, og kornmangel begyndte at vise sig, men det skyldtes ikke i første række kulden. I udlandet var der optræk til krig. Siden oktober 1739 var England og Spanien i krig, spændingen mellem Sverige og Rusland tog til, og forholdet mellem England og Frankrig tilspidsedes. ${ }^{35}$ Krig i Europa var på trapperne, og til krigsforberedelserne hørte opkøb af korn.

I Frederiksstad, Tønning og andre vestkysthavne indfandt der sig kommissærer fra hollandske og engelske kornopkøbere, og deres fangarme nåede vidt omkring. Det var de vældige opkøb, som fik prisen til at stige. Særlig slemt ville det blive, når udskibningen for alvor satte i gang ved åbent vand hen på foråret. Mangel og tåmhøje priser på hjemmemarkedet ville blive følgen, ja, hvis kulden medførte misvækst måtte man måske frygte regulær hungersnød.

De øverste regeringskollegier var klar over faren for dyrtid og kornmangel. 
Noget måtte gøres, og et udførselsforbud var det mest nærliggende middel. Et sådant indgreb var man imidlertid ikke begejstret for. Siden 1735 var monarkiets told- og handelspolitik baseret på forbud mod indførsel af korn og fri udførsel. Derved ville man beskytte det hjemlige landbrug og skaffe eksportindtægter. Indførselsforbudet gjaldt dog ikke hertugdømmerne, som derfor i mangelsituationer havde lettere ved at få forsyninger udefra end kongeriget. Den fri eksport var imidlertid overalt et fastslået princip, og regeringen standsede nødig udførslen, som gav landbruget indtægter og dermed mulighed for at betale de offentlige skatter.

Myndighederne valgte derfor en henholdende politik over for kravet om eksportstop. De lokale økonomi- og kommercekollegier blev d. 15. marts anmodet om en udtalelse, og d. 14. marts bad statholderen magistraterne $\mathrm{i}$ byerne meddele, hvorvidt de mente, at kornet havde lidt skade under frosten, om dyrtid var i vente, og om et udførselsforbud ville blive påkrævet af hensyn til almenheden. ${ }^{36}$

Af svarene fremgik, at sneen endnu hen mod 1. april lå på de lavere jorder, og at frosten ikke havde sluppet sit greb. Endnu var det for tidligt at bedømme, om sæden havde taget skade. En prisstigning regnede de fleste dog med, om end magistraterne i Tønder og Flensborg endnu var ubekymrede. I Flensborg skønnede man, at tilførsel ville holde prisen i skak. ${ }^{37}$

Håbet om tilførsler var dog næppe særlig realistisk. Tværtimod optrådte Preussen nu som kornopkøber i bl. a. Rusland, Livland og Polen, og denne efterspørgsel for at fylde de preussiske kornmagasiner kunne næppe undgå at påvirke Danmark.

Det var derfor naturligt, at mange myndigheder i Sønderjylland med frygten for en prisstigning forbandt ønsket om et udførselsforbud. Magistraten i Haderslev var mest udførlig i sin motivering: "Hvad en eventuel dyrtid angår, så kunne en sådan snarere opstå på grund af den stærke udførsel af rug og malt end på grund af en misvækst, som det endnu står tilbage at mærke, idet prisen på rug her allerede er steget over $6 \mathrm{mk}$., og samme ikke som normalt bringes til markedet $\mathrm{i}$ byen og altså næsten ikke er til at få for penge, hvilket ene og alene den stærke udførsel af samme til Tønder og videre, til udlandet, når havet atter bliver farbart, forårsager. “ ${ }^{38}$ Det synes her klart, at prisstigningen og den begyndende mangel ikke skyldtes misvækst eller den hårde vinter, men derimod kornspekulation, og at den kornforbrugende købstad havde andre interesser end landbrugerne og kornhandlerne.

På dette tidlige tidspunkt af året, hvor vintersæden (især rug) knap var kommet op, og man altså ikke kunne se, om kulden havde skadet sæden, ønskede regeringen ikke at træffe en afgørelse. Sagen blev udsat og først d. 27. 
Prisudvikling for en tonde rug i Tender og Flensborg 1740-41

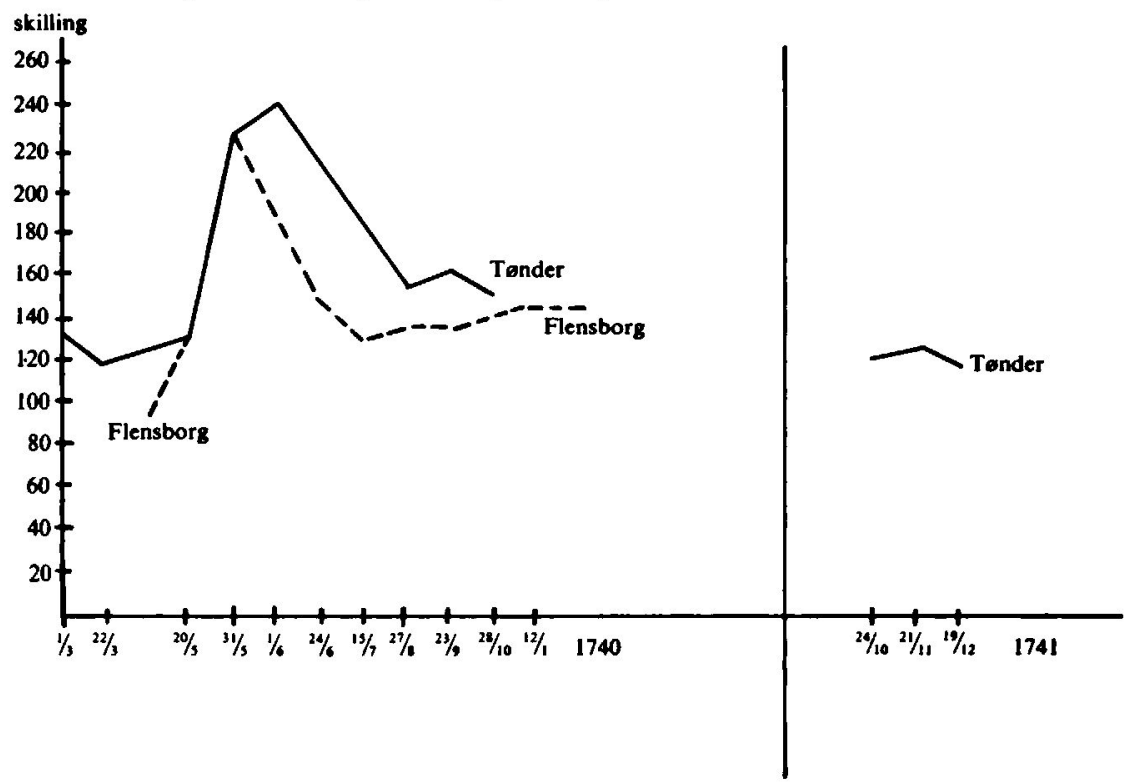

Prisudviklingen for en tende rug $i$ Tender og Flensborg $i$ 1740-41. Prisstigningen begyndie sd̀ smát $i$ marts, eksploderede med utrolig hast gennem maj máned og kulminerede forst i juni 1740. Arsagen $m a \dot{~ i s a r ~ s e g e s ~} i$ enorme udenlandske kornopkab, som tomte de hjemlige lagre og skabte mangel og nod. Efter at udforslen var forbudt d. 3. juni faldt priserne atter, men forst i efteräret 1741 fandt de igen et roligt leje. Kurven bygger pd indberetninger fra Tonder og Flensborg til Rentekammeret (kommercekollegiet), som $i 1740$ og $i$ alle senere kriseär kravede oplysninger om prisudviklingen til brug for fastlaggelsen af eventuelle regeringsindgreb. Kilde: Flensborg byarkiv 303,2 og LA Ab Tonder byarkiv relationsprot. 1740.

april anmodede kongen atter de lokale økonomi- og kommercekollegier om at ytre sig om sædens vækst, om prisudviklingen og udførslens omfang. ${ }^{39}$ Svarene indløb i slutningen af maj og åbenbarede en katastrofal udvikling. De bange anelser hos nogle tidligere på året viste sig berettigede. Kornet tegnede jæunt godt, men alligevel galopperede priserne. I Flensborg tog udførslen pludselig til hen mod midten af maj. Rugprisen steg fra 5-6 mk. pr. td. d. 7. maj til 14-15 mk. d. 31. maj. Magistraten indførte af hensyn til de fattige fast pris på alle kornarter og pålagde købmændene at sælge til denne pris. $^{40}$

Sådanne bånd på købmændene $\mathrm{i}$ Flensborg har næppe været helt uden grund, og i det fremmede havde de ikke det bedste ry på sig. Magistraten $\mathrm{i}$ Kristianssand i Norge hævdede f.eks. d. 16. juni 1740, at flensborgerne overalt i Danmark opkøbte alt det korn de kunne få, og at de danske selv bragte korn i store kvantiteter til Amsterdam. ${ }^{41}$ 
I Tønder steg prisen for en tønde rug fra lidt over $8 \mathrm{mk}$. d. 20 . maj til $15 \mathrm{mk}$. d. 1. juni, og overalt viste mangelen sig nu for alvor. Fra Løgumkloster meddelte amtsforvalter Martensen d. 27. maj, at korn ikke var til at få for penge. Flere frygtede for at skulle dø af sult, da korn var næsten umuligt at få $i$ Tønder eller andetsteds. Martensen fandt frygten begrundet, "thi hvad der endnu måtte findes af korn $\mathrm{i}$ landet, befinder sig hos nogle få folk, som har opkøbt det på ågervis og ikke sælger, før de mærker at prisen har toppet. Derfor er det nødvendigt at de kongelige magasiner åbnes for de fattige." Udskibning gjorde også sit til miseren. ${ }^{42}$

Det dystre billede fra Løgumkloster bekræftes fra Åbenrå og Tønder. Den stærke kulde $\mathrm{i}$ foråret havde medført et langt større foderforbrug end normalt, og bønderne måtte nu til byerne for at købe. Opkøbere havde imidlertid støvsuget Jylland og Slesvig og lod store ladninger udskibe til Holland og Hamborg fra Husum, Frederiksstad, Tønning og Okholm i Bredsted mellem Tønder og Husum. Fra Tønder blev kongen bestormet med den ene bøn efter den anden om at hindre udskibningen og udstede et generelt udførselsforbud, og fra Åbenrå skrev byens kommercekollegium: "Hvor meget allerede nu især ringe og fattige folk må lide derunder og hvilke andre jammerlige følger som kunne opstå, hvis ikke der træffes hurtige forholdsregler mod al fortsat blottelse af landet for korn, må kommercekollegiet ( $\mathrm{i}$ Kbh.) selv vurdere «. ${ }^{43}$

De alarmerende tilstande herskede i hele Jylland, måske især i Vestjylland. Fra Ribe klagede amtmand C. C. Gabel således d. 30. og 31. maj 1740 over kraftig kornudførsel fra Ribe stifts vestside til Holland og Hamborg. Købmændenes griskhed tyngede hårdt på fattigfolk, og "der høres allerede lamentation hos almuen, at de ikke kan få rug for penge, dels fordi købmændene haver opkøbt, hvis [hvad] de kunne falholde for at føre det ud af landet, og dels fordi adskillige, som venter dyrtid, ikke vil sælge noget af det de haver, førend prisen endnu bliver højere. “4

Kornmangelen synes at have været katastrofal. Kravet om et udførselsforbud var massivt, og regeringen måtte handle. D. 3. juni $1740 \mathrm{blev}$ al kornudførsel og brændevinsbrænding forbudt ved en trykt forordning, og det skulle overvåges, at ingen af "ukristelig vindesyge« holdt forråd tilbage og derved øgede mangelen. Der var herved taget parti for den almindelige forbruger mod spekulanterne, og princippet om fri udførsel var fraveget. Men indgrebet kom sent, og mangelen var ikke dermed afhjulpet. Yderligere indgreb var nødvendige for at sikre undersåtterne det nødvendige brød - og sædekorn. Atter valgte regeringen imidlertid at gå forsigtigt frem. Den lod alle lokale ovrigheder spørge om den lokale forsyningssituation og om forslag til afhjæelpning af nøden. ${ }^{45}$ 
Indberetningerne viste, at forrådene var meget beskedne, om end de nok kunne ernære befolkningen indtil høsten. Magistraten i Haderslev klagede over mangel og forbød egenhændigt udførsel fra byen og salg til amtet. I Tønder og omegn var mangelen måske større, og bystyret lod indforskrive 750 td. rug til billig overladelse til de fattige. ${ }^{46}$ Hverken Å benrå amt eller by var blottet for kornforråd og indforsel hjalp på vanskelighederne. Problemet lå snarere i forrådets ulige fordeling. Nogle få kunne klare sig til næste høst, som tegnede godt, men mange manglede forråd og kunne ikke betale den høje pris. Amtsforvalter Martensen i Løgumkloster mente som tidligere, at størstedelen af kornet lå hos dem "som på ågervis har opkøbt alt korn som var at få. Men disse folk vil holde inde med salg indtil der ikke er noget at få hos andre, så de der mangler korn er nødt til at betale dem alt hvad de forlanger." Over for disse ågerkarle var skrappe midler nødvendige. Martensen foreslog maksimalpris og salgstvang, og for at få kornhandlerne og storbønder til at sælge af kornforrådene ønskede han, at gæld for indkøbt korn skulle have prioritet forud for anden gæld. Endelig ønskede han, at de kongelige magasiner skulle forstrække de trængende med korn - dette ville også automatisk tvinge kornhandlerne til at sætte prisen ned. ${ }^{47}$ Amtmanden $i$ Ábenrå tilsluttede sig i det store og hele Martensens mening - foreslog maksimalpris, at folk med overskud skulle sælge til denne pris, evt. på kredit, og at de kongelige magasiner skulle forstrække med korn indtil høst. Ønsket om salg fra de kongelige magsiner lød også hyppigt fra byerne i Holsten.

Så langt ville statsmagten dog ikke gå. D. 18. juni vedtog rentekammeret for at fremme salget til de trængende, at såfremt de købte på kredit, så skulle sælgerens tilgodehavende have forrang i tilfælde af konkurs. Yderligere fritog man d. 2. juli korn for importtold og licent. ${ }^{49}$

Noget hjalp dette. Eksempelvis "blev af kongens tilladelse indført til Haderslev 600 td. magasinrug, hvoraf enhver efter nødtørft fik, at låne til på andet år, da det blev betalt med en sk. (skæppe?) abod (?) på tønden og $1 \mathrm{mk}$. til fragt. ${ }^{50} \mathrm{På} \mathrm{den} \mathrm{måde} \mathrm{søgte} \mathrm{man} \mathrm{at} \mathrm{sikre} \mathrm{den} \mathrm{livsnødvendige} \mathrm{såsæd.} \mathrm{Mere}$ radikale midler afvistes. Magistraten i Haderslev fik at høre, at dens udførselsforbud var ulovligt. Den måtte i stedet skaffe korn fra nabobyerne. Over for amtmanden i Åbenrå blev ideen om maksimalpris og tvangssalg imødegået med den bemærkelsesværdige indvending, at en fast pris og tvangssalg var betænkeligt, så længe der var andre udveje, »især da der i køb og salg bør bevares en uindskrænket frihed. “ Dog godkendte statholderen den prisfastsættelse og regulering af kornsalget, som var sket $i$ Flensborg og bad magistraten fortsætte dermed "til bedste for de ringe borgere og indbyggere. ${ }^{51}$

Med forbud mod udførsel og brændevinsbrænding, toldfri kornimport og 
kreditbegunstigelser søgte regeringen at løse befolkningens problemer. Faktisk faldt priserne, og i august kostede en tønde rug i Tønder ca. 10-11 mk. mod 15 i slutningen af maj, og i Flensborg lidt over $8 \mathrm{mk}$. Og høsten nærmede sig. Med iver indkrævede regeringen stadig oplysninger om kornets udvikling, og hver uge skulle de lokale øvrigheder indberette om prisudviklingen. Udviklingen forekom gunstig, og regeringen greb chancen. D. 13. aug. blev brændevinsbrænding atter tilladt, og efter en temmelig god høst, især af rug, blev kornudførslen d. 17. sept. givet fri.

Men regeringens iver $\mathrm{i}$ den fri udfarsels tjeneste viste sig overilet. Flere forhold antydede en kommende mangel. Boghvedehøsten var ringe og medførte et større forbrug af rug til grød; under mangelen i forsommeren havde mange måttet låne brødkorn på den kommende høst. Lånene skulle nu betales tilbage. Det gjorde på forhånd indhug i høsten. ${ }^{52} \mathrm{Nu}$ kom udførslen til. Fra Haderslev klagede borgerskabet over, at korn atter i mængde blev udført fra amtet til Tønder, Husum, Åbenrå og Flensborg, at der kom for ringe forsyninger til byen, og at mangel og prisstigninger truede. ${ }^{53}$ Også fra Flensborg hed det, at kornet på vestkysten blev bragt til Hamborg m. m., og at det korn som normalt blev indført til Danmark, nu på grund af den vedvarende krig blev ført til England, Holland, Frankrig og Spanien. De alarmerende meldinger virkede, og d. 24. okt. 1740 måtte al eksport af korn atter forbydes. Herefter fulgte regeringen opmærksomt udviklingen. Hver uge, senere månedligt skulle der indberettes om kornprisen og senere om forrådet.

Denne opmærksomhed var berettiget. Hård vinter, stor eksport, eksportstop ved Østersøen skabte problemer først på året 1741 , og først efter en tilfredsstillende høst og faldende priser i 1741 gav man d. 4. sept. 1741 på ny eksporten fri. Dermed var 1740-41-krisen afsluttet.

Disse år afslører bemærkelsesværdige træk om tidens samfund. Voldsomme prissvingninger kunne gøre eksistensen næsten umulig for måske hovedparten af befolkningen. Naturens luner var med til at fremkalde vanskelighederne, men de var ikke den afgørende faktor. Man får således ikke den fulde forklaring, når man læser $i$ sandemand Anders Petersens optegnelser, "at det var i samme år (1740) en meget hård vinter og forår, ved vinter tid galt 1 skæppe rug 11 a 12 skl., men som foråret blev så hårdt, gik 1 skæppe på 1 mark og hen i sommeren på $1 / 2$ rdl.. ${ }^{50}$ Tværtimod var det udenlandske opkøb som led i krigsforberedelser, som forårsagede krisen. Eksport, kornhandleres kneb og vindesyge var hovedsynderne. ${ }^{55}$

Disse fænomener delte befolkningen $\mathrm{i}$ klasser med helt forskellige interesser. Småfolk på land og i by, forbrugerne og byernes øvrigheder, tordnede over opkøbernes og de handlendes griskhed, som drev prisen i vejret. De 
handlende og producenterne krævede fri handel og søgte at bagatellisere problemerne. Et særligt veltalende udtryk for disse interesser får vi fra de kornproducerende marskegne. Fra Nord- og Sydditmarsken og fra Krempeog Wilster-marsken søgte man gang på gang om fri udførsel. Udførselsforbudet trykkede nemlig priserne og hindrede bønderne $i$ at erhverve den salgsindtægt, hvormed de skulle betale de kongelige skatter. Særlig markant var holdningen i Krempe- og Wilster-marsken, hvor et forslag fra amtmanden om at indkøbe et større parti rug, som kunne sælges billigt, til de fattige blev afslået. Man foretrak en anselig salgspris, og fra Krempemarsken fremhæves, at en for lav kornpris var uønsket, da den gjorde daglejerne krævende. De blev svære at få fat på, skulle bevæges med gode ord og henfaldt ved salg af korn på kredit til dovenskab. Ved en høj pris var det lettere at holde dem i tømme og samtidig blev salgsindtægterne, bøndernes livsgrundlag, bedre. ${ }^{56}$

Disse synspunkter var dog ikke regeringens. Den var ganske vist af hensyn til landbrugets rentabilitet og skatteevne utilbøjelig til at hindre korneksporten, men blev dyrtiden og mangelen akut, accepterede den alligevel, at der måtte gribes ind til forbrugernes og byernes gavn med eksportstop, stop for brændevinsbrænding og leverancer fra de kongelige magasiner. Særlig vigtigt var det at sikre landbruget den sæderug, som var grundlaget for næste års høst, og derfor indførtes regler til lettelse af bøndernes indkøb af brød- og sæderug. Regeringen var altså villig til at bøde på kornspekulationens virkninger, men det skete tøvende af hensyn til handelsbalancen og landbrugets skatteevne.

\section{$1756-59$}

I 1756 trak uvejrsskyer atter op over Europa. I 1755 slog høsten fejl i flere lande, og i juni 1755 udbrød der fjendtligheder mellem England og Frankrig. Over for den truende krigsfare indgik de skandinaviske lande i juli 1756 et væbnet neutralitetsforbund. I august trængte Frederik II ind i Sachsen og indledte dermed den preussiske syvårskrig.

Allerede ved midsommertid mærkedes følgevirkningerne i Danmark. I Flensborg svigtede tilførslerne af levnedsmidler og brændsel fra indlandet. Varerne blev tilsyneladende opkøbt hos bønderne inden de kom til marked $i$ byen, og følgen blev prisstigning og mangel for den lille forbruger. For at sikre varer til alle, også de mindre kapitalstærke, kundgjorde magistraten derfor d. 18. juni, at der ikke måtte købes direkte hos bønderne. Varerne skulle føres til marked $\mathrm{i}$ byen, og her måtte ingen købe mere, end han selv kunne bruge. Kapitalstærke købere skulle altså ikke have lov til at hamstre. 
Akut var situationen dog langtfra, idet byen på denne tid fik store tilførsler af korn såvel fra Østersøen som fra Holland og Hamborg. ${ }^{57}$

Priserne steg overalt, ikke blot i Flensborg. Sandemand Anders Petersen i Ørsted skrev: $" 1$ sk. rug koster først i året (1756) 10 a 11 skl., en sk. byg 8 skl. en sk. boget [boghvede] 5 a 6 skl. Men hen midt i sommeren koster 1 sk. rug over 1 mark. En sk. boget 12 skl. og var end da trang at få det samme. ${ }^{50}$

Regeringsmyndighederne fulgte atter nøje udviklingens gang og lod forespørge, om prisstigningen af hensyn til de fattige krævede et forbud mod brændevinsbrænding eller andre indgreb. Svarene viser, at problemer var under opsejling. I Haderslev var rug i juni måned næsten slet ikke til at få for penge, hverken for det almindelige borgerskab eller de indkvarterede soldater, og man bad om at måtte få billigt korn fra de kongelige magasiner. ${ }^{58}$ Noget lignende var forholdet i Tønder. ${ }^{99}$

Om årsagen til prisstigningerne herskede der på denne tid nogen uklarhed. Korn blev næppe eksporteret i større mængder, og tilførslerne var ikke ubetydelige. Men det forlød, at mange holdt deres korn tilbage i håb om lukrativ afsætning til de krigsførende magter, og at dette pressede prisen op. ${ }^{60}$

Det var først $\mathrm{i}$ efteråret, at udførsel begyndte at påvirke forsynings- og prissituationen. Man kunne have ventet, at høsten fik priserne til at falde. Men det gik modsat. Dels blev høsten nemlig ret dårlig, og dels blev

Prisudvikling for en tende rug i Tender os Flensborg 1755-1759

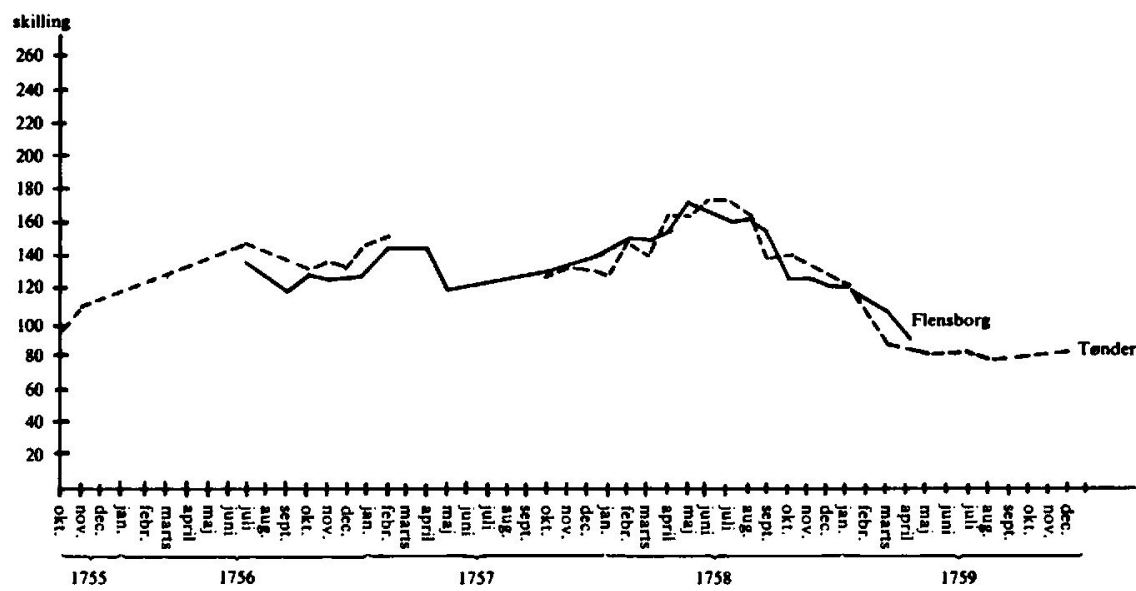

Prisudviklingen for en tende rug i Flensborg og Tender 1755-59. Omend kurverne er mangelfulde viser de et karakteristisk forlob. Indil juli 1756 var priserne opadgdende bl.a. pá grund af spekulationsopkab, og den påfolgende middelmådige host betod kun et kort prisfald. Ny prisstigning fulgte, og det er karakteristisk, at priserne normalt toppede i ford̈ og forsommer inden hosten. Kilde: LA Ab Tonder byarkiv, relationsprotokoller og Flensborg byarkiv nr. 303.2. 
kornhandelen grebet af spekulation. Ved Østersøen blev korneksport forbudt, og Preussen optrådte som opkøber. Fra Hamborg og Holland blev efterspørgslen efter korn i Vestslesvig stærk, og samtidig blev tilførsel fra Danmark hindret af forbud. Dette skabte naturligt mangel og prisstigning i hertugdømmerne. Men i øvrigt ramte prisstigningen hele Europa, forårsaget af dårlig høst og krigsspekulation.

Nogle detaljer vil vise forløbet. Allerede d. 1. sept. kunne magistraten $i$ Flensborg meddele, at kornhandelen var grebet af spekulation. Preussen havde forbudt korneksport og købte op i udlandet og prisen steg. ${ }^{61}$ I den følgende tid lød der næsten enslydende beklagelser fra alle egne af hertugdømmerne.

Prisen i Hamborg steg og steg, og opkøbere fra Holland og Hamborg udskibede mængder af korn fra vestkysten med prisstigning og mangel til følge. Kravet om at standse denne eksport til gavn for forbrugerne lød højt fra f.eks. Flensborg, Itzehoe og grevskabet Rantzau, og magistraten i Tønder fremhævede, at det ville have de uheldigste følger, hvis ikke opkøbene i by og på land blev begrænset. Og den fortsatte: "Navnlig da det nu er kun altfor tydeligt, hvor stor den vindesyge er, som besjæler de fleste købmænd, eftersom næsten enhver søger at lukrere på de betragtelige kornpriser $\mathrm{i}$ Hamborg. Og som disse folk alene vil befordre deres privatinteresser endog på bekostning af deres forpligtelser over for almenvællet, således må et godt styre, når publikum skades derved, ikke tage hensyn hertil, men må sætte sig ud over det." Derfor bad også Tønder om forbud mod korneksport og udskibning til bl.a. Hamborg. ${ }^{62}$

Sådan talte evrigheden i et kornforbrugende bysamfund. Den modsatte holdning kom til orde i Sydditmarsken. Da sognefogeder og fuldmægtige her så, at det trak op til et udførselsforbud, lagde de deres stemme i vægtskålen for at hindre det. ${ }^{63}$

Magistraten i Sønderborg fremhævede derimod i oktober 1756, at den høje pris gjorde kornindførsel fra Danmark nødvendig, ligesom korneksporten fra hertugdømmerne måtte forbydes, da man ellers måtte frygte mangel på levnedsmidler. ${ }^{64}$

De alvorlige klager gjorde indtryk. D. 13. oktober skred den storfyrstelige regering ind mod eksporten, som $\mathrm{i}$ »uhæmmet profitbegær r fik priserne til at stige. Regeringen i København udstedte tilsvarende d. 25. okt. forbud mod korneksport fra Slesvig, ${ }^{65}$ og toldforvalterne ilede af sted for at beslaglægge kornskibe på vej mod markederne i Vesteuropa. Samtidig blev det forbudt $\mathrm{i}$ "ukristelig vindesyge“ at holde korn tilbage. Disse bestemmelser blev naturligt nok hilst med tilfredshed af byernes $ø v$ righeder og forbrugerne, men med kulde af de handlende. 
Forbudet løste dog ikke alle vanskeligheder, og det dæmpede kun i ringe grad prisstigningen. I kongeriget havde korneksport været forbudt siden 29 . maj 1756, og det $ø$ gede mangelen i Slesvig, som normalt aftog en del korn fra Jylland og øerne. Desuden forlød det, at kornhandlere og bønder stadig holdt korn tilbage $\mathrm{i}$ håb om, at handelen inden længe atter blev frigivet med stigende priser til følge. ${ }^{66}$ Samtidig var efterspørgslen fra de krigsførende lande fortsat stærk, og det forlød, at ulovlig udførsel trods forbudet gik i svang. Det holdt alt sammen priserne oppe. Så meget mere væsentligt var derfor udførselsforbudet, og magistraten i Flensborg betragtede det da også som det eneste værn mod mangel og dyrtid. Hvis udførslen atter blev tilladt, ville hele forrådet blive opkøbt af de krigsførende magter.

I Sønderborg klagede man over, at bønderne hellere udskibede kornet direkte frem for at føre det til byen, med prisstigning til følge. Af hensyn til de ubemidlede blev det også nødvendigt for magistraten at gribe ind mod bagerne, som bagte undervægtige brød af dårligt mel og mod bønderne, som sagdes at bringe "forfalsket" korn til marked. ${ }^{67}$

Der var altså grund til bekymring, og i 1758 toppede priserne. Udførselsforbudet måtte derfor opretholdes, om end det ikke synes at være blevet overholdt, $^{68}$ og såvel Tønder som Åbenrå magistrater bad om at måtte forbyde brændevinsbrænding til gavn for fattigfolk. ${ }^{69}$ Regeringen lod sig løbende underrette om kornpriser og forråd, og endelig efter høsten i 1758 bevægede priserne sig atter ned $i$ et moderat leje. Langt om længe kunne man da d. 16. juni 1759 atter give udførslen fri.

Overskuer man nu disse år fra 1756-59 må det vel atter konstateres, at prisstigninger og mangel ikke var et resultat af blot det hjemlige høstudbytte. Dette virkede snarere sammen med udefra kommende påvirkninger, dårlig høst i udlandet, krigsforhold og opkøb. Sammenfald af disse uheldige faktorer var afgørende for vanskelighedernes omfang, og atter måtte staten gå på akkord med sit finansielt betingede ønske om fri eksport.

\section{2}

I 1762 stod man atter over for en kornkrise med krav om ekstraordinære foranstaltninger. Årsagen var igen prisstigninger. Ved udgangen af 1760 svingede prisen for en tønde rug omkring 5 mark, men op mod jul 1761 var prisen i Tønder steget til $7 \mathrm{mk}$. 10-12 skl. (2 rdl. 26-28 skl.). Bager-, skrædder-, skomager- og smedelavene klagede over de trykkende priser, og magistraten var i vildrede. Den vidste ikke, om dyrtiden skyldtes bønders og kornkøbmænds spekulation eller en kraftig udførsel. ${ }^{70}$

Snart fandt regeringen det imidlertid begrundet at gribe ind, og hertil kan 


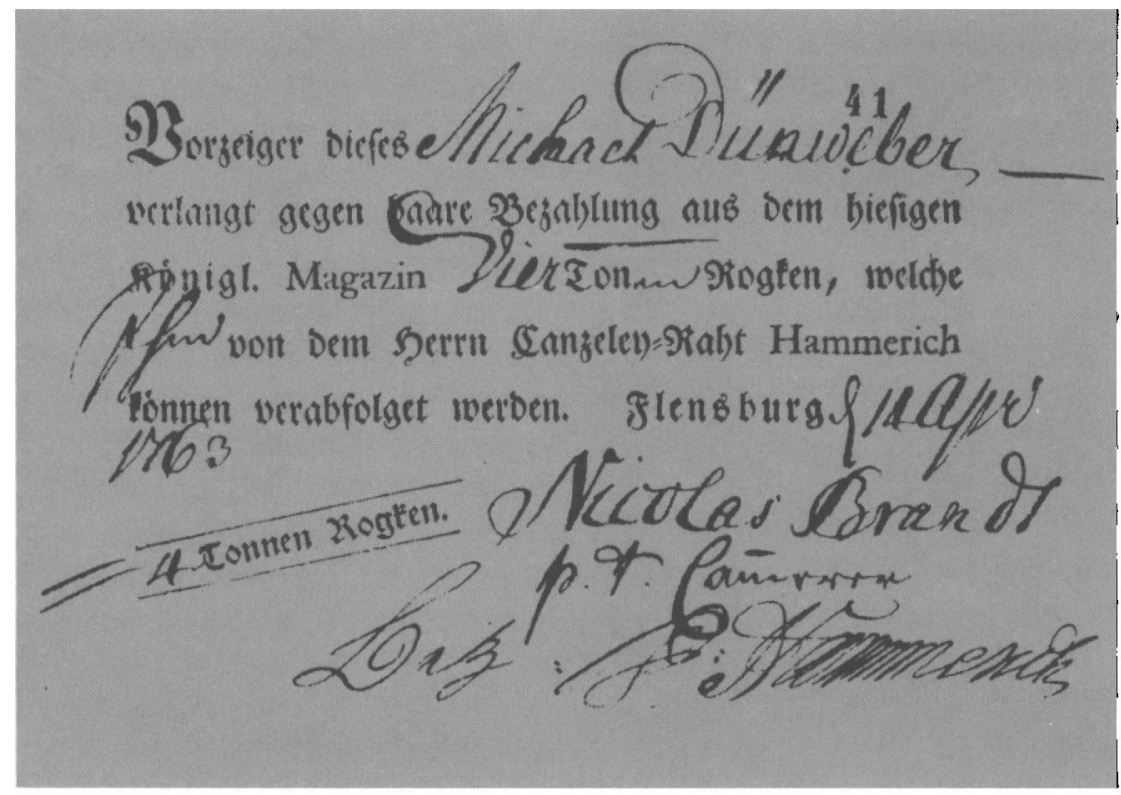

"Kornbillet" fra Flensborg 1763. Mod aflevering af "billetten $i$ det kongelige kornmagasin kunne ihandehaveren kabe $4 \mathrm{td}$. rug til moderat pris (Flensborg byarkiv nr. 845).

de kritiske udenrigspolitiske forhold have bidraget. Allerede i 1761 trak det op til krig, og bønderne blev pålagt ekstra leverancer til hæren. D. 5. jan. 1762 døde kejserinde Elisabeth af Rusland, og Danmark-Norges dødsfjende, gottorperen Karl Peter Ulrich besteg den russiske trone under navnet Peter III.

Straks blev der truffet krigsforberedelser, og måske kan et patent af 16. febr. 1762 betragtes som led heri. Al kornudførsel fra Slesvig og Holsten blev forbudt, og forråd af rug og havre skulle mod betaling afleveres til de kongelige magasiner. ${ }^{65}$ Herefter blev det overalt kundgjort, at alle rug- og havreforråd, altså alt med undtagelse af det nødvendige brød- og sædekorn, var beslaglagt og skulle indgå i de kongelige magasiner. Forrådene viste sig dog beskedne. For Haderslev by hed det, at der intet var til overs, og at man tværtimod ventede rug-tilførsel fra Riga. ${ }^{71}$ I Løgumkloster amt var der hos de største producenter (præster, møllere, større forpagtere) et forråd på 335 td. rug og i Åbenrå amt 679 td. rug, men der var ikke taget hensyn til husmænds og indersters forbrug. Især i Løgumkloster amt klagede disse allerede over, at korn næsten ikke var til at få for penge, og derfor foreslog amtmanden, at magasinerne skulle sælge brødkorn til de fattige. Kun på den måde kunne 
stor nød forhindres. Åbenrå Slots- og Nymølle og Rundemølle i Løjt sogn havde heller ikke noget at afgive. De solgte nemlig hver lørdag korn til de fattige, og de havde ikke kunnet klare efterspørgslen. ${ }^{72}$

De ret ensartede indberetninger om beskedne forråd fik d. 17. april rentekammeret til at ophæve bestemmelsen om beslaglæggelse, hvorefter kornet atter frit kunne afsættes indenlands, og d. 4. aug. 1762 tillod man igen korneksporten. $^{65}$

Helt var priserne dog ikke faldet til ro. Alarmerende meldinger om prisstigninger fik derfor rentekammeret til d. 23. nov. 1762 at tillade, at der blev solgt korn til de fattige fra de kongelige magasiner. Formålet var at dæmpe prisstigningerne. I Flensborg fik magasinet lov til at afgive $3.000 \mathrm{td}$., og magistraten lod fremstille billetter, som gav ret til at få udleveret 1-4 td. rug mod en betaling af 2 rdl. $24 \mathrm{skl}$. Denne ordning blev praktiseret til april $1763 .^{73}$

Alt i alt var 1762 et kriseår, og det på mange måder. Høsten slog fejl flere gange først i 1760'erne, og krigstruslen svævede over landet. De udenrigspolitiske forhold har næppe heller denne gang været uden indflydelse på den hjemlige udvikling; staten måtte gribe ind med eksportforbud og salg fra magasinerne for at lette den akutte mangel.

\section{$1770-1772$}

De følgende år blev mere normale, men uheld kunne altid indtræde. Om året 1768 berettede sandemand Anders Petersen i Ørsted: „Dette års rug var så såre ringe, at det var ynkelig at se, vi aulede vel 22 traver efter 6 tønder sæd, der af fik vi ikkun $4 \frac{1}{2}$ td. af al vores auling, der var mange traver som ikke gav a trav $1 / 2$ skip og mange slet intet. Af samme $4 \frac{1}{2}$ tønde, såede vi 4 td., havde altså ikkun 4 skip til husholdning til et år, der til købte vi $3 \mathrm{td}$. a td. $10 \mathrm{mk}$. af det rug som kom fra Dantzig, vi brugte mere end halvdelen bygmel stedse $\mathbf{i}$ brødet det hele år, vi avlede 20 trav byg som gav $16 \mathrm{td}$. i alt, hvilket var vores eneste føde."

I 1769, det følgende år, blev høsten kun mådelig, priserne steg, og fra Ørsted læser vi, at "fattigdom forøges meget over alt, af fæsygdommen, og af kornets misvækst $\mathrm{i}$ disse åringer." ${ }^{50}$

Endnu værre blev det $\mathrm{i}$ årene 1770-72, som i Europas historie er blevet kendt under betegnelsen "Hungerårene«. Misvækst hærgede, kornmangel, dyrtid og stigende dødelighed spores i land efter land. Mange måtte slå ind på en ny afgrøde, kartofler, og ikke få i Tyskland måtte tage til takke med rødder og grøntsager. Europas kornkammer ved Østersøen, Polen, Pommern og Mecklenburg, blev hårdt ramt af misvæksten. I Preussen blev der indrettet 
kornmagasiner, priserne blev reguleret af staten, udførsel blev forbudt, og det offentlige købte korn op i ind- og udland til gavn for befolkningen. ${ }^{74}$

Krisen gik heller ikke uden om Danmark $\mathrm{i}$ disse år, Struensees magtperiode. I 1770 blev sommeren kold, våd og ufrugtbar, isar i høstens tid, kornet slog fejl, og blev mange steder vådt og slet indbjerget. Følgen var dyrtid, og da vinteren $1770 / 71$ blev barsk, hørtes overalt klager over høje kornpriser, almindelig fattigdom og fødevaremangel, og det var svært at få tilførsler fra udlandet. ${ }^{75}$ I København klagede magistraten over kornmangel, og bad om udførselsforbud. D. 3. nov. 1770 blev ønsket efterkommet, og det blev også forbudt at brænde brændevin af rug. Struensee-regeringen viste sig mere villig til at tillade kornimport end de mere merkantilistiske forgængere. $^{26}$

I oktober måned 1770 blev vanskelighederne for alvor mærkbare i Sønderjylland. Høsten havde været ret ringe, og til yderligere forværring af situationen skete der nu store opkøb fra udlandet, hvor misvækst var åbenbar. Allerede d. 6. okt. 1770 udtalte amtmanden i Åbenrå over for rentekammeret, at der skete store opkøb fra Preussen, hvor man anlagde kornmagasiner. Amtmanden ville gerne unde folk at salge korn til de udenlandske opkøbere og derved bringe penge til landet. Men den uindskrænkede kornudførsel ville snart skabe dyrtid og mangel. Derfor foreslog han, at undersåtterne skulle forpligtes til at holde et vist kvantum korn tilbage, og at udførslen, når hjemmemarkedet således var sikret, $i$ øvrigt skulle være fri. ${ }^{77}$ I Tønder klagede de deputerede ligeledes kort efter over en hyppig udskibning af korn og bad om udførselsforbud. ${ }^{78}$

Foruroliget over prisstigningen indkaldte såvel rentekammeret som statholderen derpå oplysninger om forrådene af korn. Rapporterne fremhævede overalt de stigende priser og det beskedne forråd. Fra Åbenrå by klagede magistraten især over, at de normale kornleverandører i udlandet havde forbudt udførsel og i stedet optrådte som opkøbere i Danmark. Udførslen var stærk, og der gik rygter om, at mange producenter havde aftalt salg til udenlandske opkøbere. ${ }^{79}$ Fra Haderslev fremhævede magistraten, at rughøsten havde været meget ringe, i Tønder mente man, at høsten ikke havde været som $\mathrm{i}$ gode år, ${ }^{80}$ og fra Løgumkloster meddelte amtsforvalter Lucas, at der intet var tilbage af forrige års afgrøde. Af høsten 1770 ville der kun blive meget lidt tilbage, når det nødvendige forbrug indtil næste høst gik fra, ja nogle ville ikke kunne klare sig så længe med det indhøstede. ${ }^{81}$ Fra Als og Sundeved hed det samstemmende, at rug-og boghvedehøsten ikke var faldet godt ud, og at mange bønder delvis manglede det nødvendige forråd til husholdningen. ${ }^{82}$

I Ørsted skrev sandemand Anders Petersen: "... vores auling var (1770) 
utilstrækkelig dels af misvækst, og dels at vi ved landeriets deling var udkommen af den ordentlige sæd. ... Kornet er nu i nogle år misvokset her i landet og fæsygdommen vedvarer, så er her ud af kommen så stor fattigdom over alt $i$ landet, at der i mands minde ey er erfaret slig trang som nu er. ${ }^{50}$ Også fra Holsten, f.eks. Pløn, berettes, at høsten 1770 var slået fejl. ${ }^{83}$

Situationen efter den dårlige høst var så alvorlig, at regeringen måtte tage hensyn til de stærke ønsker. Under indtryk af prisstigning og frygten for kornmangel blev udførsel forbudt d. 5 . nov. $1770,{ }^{65}$ men priserne faldt ikke af den grund. Det gjaldt om yderligere at begrænse efterspørgslen på det livsnødvendige brødkorn. Regeringen bestemte følgelig d. 11. febr. 1771 »til det almindelige og især de fattige af vore kære og tro undersåtters, deres bedste « at forbyde al brændevinsbrænding af rug. ${ }^{65}$

Forordningen var sikkert tiltrængt, og har nok vakt glæde i Tønder, hvor de deputerede og byens fattige i det tidlige forår klagede højlydt over den usædvanlige dyrtid og de fattiges nød, ikke mindst forårsaget af bønders ulovlige opkøb og indskibning af korn til eksport. ${ }^{84}$

Også på anden måde søgte regeringen at sikre det nødvendige kornforråd. D. 5. nov. 1770 havde man bestemt, at bønderne skulle opbevare den udskrevne magasinrug i natura - derved var man sikker på, at der blev holdt et forråd tilbage til en mangelsituation. Hen på foråret 1771 viste mangelen sig da også i mange bøndergå rde med fornyet styrke. Til regeringen indløb fra mange egne klager over, at bønderne manglede det nødvendige korn til husholdningen, og d. 17. april 1771 tillod man derfor bønderne at inddrage den reserverede magasinrug til eget brug - dog naturligvis mod betaling til staten. $^{85}$

Denne lempelse var sikkert berettiget, for en lang vinter øgede vanskelighederne. Man læser, at folk d. 13. april 1771 gik »på isen fra Kegnæs til Als, og den 4. maj lå der megen sne bag gærderne og megen is i havet, så at søfolkene ingensteds kunne komme ${ }^{86}$

Trods de høje priser og mangelen var regeringen imidlertid ikke glad for udførselsforbudet, som berøvede landet de eftertragtede eksportindtægter. Det var et middel, som man kun ville anvende i en helt akut nødsituation, og så kortvarigt som muligt. Så snart vandene blev åbne efter vinteren, og indførsel altså blev teoretisk mulig, ophævede man derfor i maj 1771 forbudet. ${ }^{65}$ Forbrugerne var naturligvis utilfredse, ikke mindst da høsten atter slog fejl i 1771 og tilførslerne udeblev på grund af misvækst og udførselsstop i udlandet. Amtmanden i Åbenrå kunne i november 1771 fremhæve, at en fugtig, middelmådig og sen høst og beskedne muligheder for tilførsel fra østersølandene truede med at skabe forsyningsproblemer for de fattige. Det fugtige efterår vanskeliggjorde også såningen, og han frygtede, at 
brødkorn til foråret ville blive meget dyrt og næppe til at få for penge. For at hindre udførsel af rug foreslog han derfor, at undersåtterne skulle pålægges at holde dobbelt så meget magasinrug tilbage som normalt. ${ }^{87}$ For Åbenrå amt gjaldt iøvrigt, at høsten af rug, havre og byg de fleste steder kun havde været middelmådig, og at kun boghveden var faldet godt ud. ${ }^{88}$

Fra Ørsted berettes (1771) tilsvarende, at »kornet blev meget dyre ... Da alt landet nu næsten er nedsynket $\mathrm{i}$ armod, så forefalder mange konkurser. Gårdene koster ikkun lidet, de fattiges tal er utallig som betler, mange lider hunger, den ene kan ey hjælpe den anden, mange giver dem til stjælen og røven, så mand næppe er sikker for tyverier, ja usædvanlig ildebrand erfares, så at fornemmes mange selv med forsæt afbrænder hus og hjem. “ ${ }^{\text {s0 }}$

Her males i drastiske farver, og i byerne lyder det også ilde. Flensborg magistrat bad p.g.a. ringe tilførsel udefra gentagne gange om et udførselsforbud, og fandt det for at modvirke mangel og dyrtid nødvendigt af hensyn til de fattige at indkøbe $200 \mathrm{td}$. rug. Kornet blev lagt hen til salg i små portioner for indkøbsprisen. ${ }^{89}$

I Åbenrå frygtede magistraten ligeledes, at de høje kornpriser ved en stærk udførsel ville stige endnu mere, og i foråret 1772 skabe mangel. Af hensyn til de fattige tilrådede man derfor et forbud mod korneksport. ${ }^{90}$

Regeringen var imidlertid på dette tidspunkt, efter Struensees fald, ikke lydhør. Den overhørte klagerne, og priserne forblev i et højt leje. Man nøjedes med også for året 1772 at kræve opbevaring af magasinrug i natura, for derpå i april 1772 at give den fri til forbrug, fordi mange atter manglede det nødvendigste til husholdning og udsæd. ${ }^{91}$ Dette viser endnu engang, at mangelen og dyrtiden vedblev i første del af 1772 . I september 1772 hører vi f.eks. fra Flensborg klager over, at kornmangel og dyrtid havde været slemme lige indtil høsten 1772, og at kraftig udførsel fra vestkysten til Holland berøvede hjemmemarkedet et forråd, som på grund af eksportstop ved Østersøen ikke kunne skaffes fra anden side..$^{92}$ I Ørsted var kornet på samme tid dyrt og næppe til at få for penge. ${ }^{50}$

Det værste var dog overstået. Høsten 1772 blev rimelig god, priserne begyndte at falde, og da udbyttet steg yderligere næste år, forstummede klagerne lidt efter lidt. Prisfaldet illustreres i Chresten Chrestensen Kaads dagbog fra Hørup sogn, hvor det hedder: "I februar (1773) kostede kornet rug $20 \mathrm{skl}$., byg $19 \mathrm{skl}$, havre $10 \mathrm{skl}$., tade (boghvede) $6 \mathrm{skl}$., men i september kun det halve. ${ }^{86}$

Sammenfattende må man konkludere, at årene 1770-72 har været præget af en meget alvorlig kornmangel og deraf følgende dyrtid. Årsagen må iførste række søges i flere på hinanden følgende dårlige høstudbytter. Men den kraftige efterspørgsel fra udlandet, som også var ra mt af misvækst og mangel, 
og den deraf følgende kornspekulation har, kombineret med svigtende tilførsler fra Østersøområdet, været en medvirkende årsag. Regeringen erkendte vanskelighederne, forbød eksporten, men kun for en tid; man ville ikke i længden stoppe den korneksport, som nok virkede fordyrende, men også skaffede eksportindtægter.

\section{0'erne}

De besværlige år omkring 1770 blev afløst af en tid med overflod af korn og lave priser sidst i 1770 'erne. Dermed ophørte al tale om forsyningsproblemer. Samtidig vendte regeringen $i$ forstærket grad tilbage til den traditionelle beskyttelsespolitik og ønskede på enhver måde at hindre pengestrømmen til udlandet. ${ }^{76}$ Som udtryk for denne holdning forbød man nu import af rug til hertugdømmerne (1777 17/3, 1777 1/12, 1778 14/12 til $178211 / 11)$.

Hidtil havde et sådant importforbud kun været gældende i kongeriget (siden 1735), mens hertugdømmerne havde kunnet indføre korn, til gavn for forsyningen i mangelperioder. I kriseår havde befolkningens bønskrifter derfor hidtil kun talt om eksportforbud - nu gjorde importstoppet problemerne værre i kriseår. Det viste sig omkring 1780.

Allerede i 1779 steg priserne efter en middelmådig høst året før, og de fortsatte med at stige i 1780 efter tørke og en dårlig høst. Derfor bad byer som Altona, Flensborg og Sønderborg først på året 1781 om tilladelse til at måtte indføre rug - for at hjælpe de fattige, hindre hungersnød og dæmpe priserne. ${ }^{93}$ Flensborg fremhævede særligt, at prisstigningen også kunne skyldes krigsuro i udlandet, som øgede efterspørgslen fra magasinerne og dermed skabte mulighed for en lukrativ eksport, med mangel på hjemmemarkedet til følge.

Regeringen fulgte som følge af klagerne nøje høstudbyttet, men først efter megen regn og en temmelig dårlig høst $\mathrm{i} 1782^{50}$ fandt man anledning til at tillade import fra 11. nov. 1782. Det viser, at mangelen må have været betydelig i 1782, og det var ikke kun kornmangel, som plagede den jævne befolkning. Også smørret blev knapt og dyrt. I Åbenrå klagede håndværkerne i september 1782 over, at smør blev opkøbt på landet, at det steg i pris og næppe var til at få fat på. Magistraten var enig med klagerne og ønskede at tvinge bønder, som kom til byen, til at sælge på torvet til den menige forbruger i stedet for til opkøbere. Få dage efter søgte tømrere og andre jævne håndværkere at tvinge en skipper til at sælge dem noget smør, som skulle til København, og det kom til demonstrationer i protest mod smørmangelen. ${ }^{95}$

Trods disse vanskeligheder var det dog kun nødtvunget regeringen havde tilladt kornimport. Men de følelige vanskeligheder vejede tungt, og da høsten 


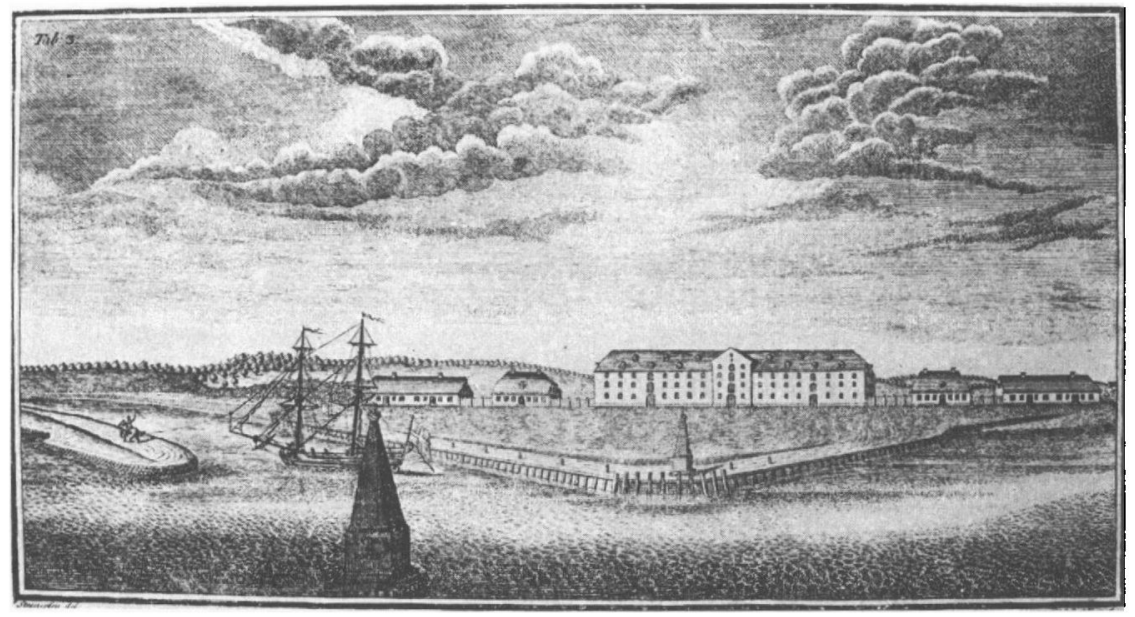

Ejderkanalens ostlige munding ved Holtenaa. I baggrunden det store kanalpakhus, som havde pendanter $i$ Rendsborg og Tonning. En fuldrigger er på vej ind $i$ kanalen, måske ladet med korn fra Danmark eller Osterselandene. En stor del af korneksporten fra Østerseen (byer som Rostock, Memel, Wolgast, Königsberg, Wismar osv.) og Danmark til Hamborg, Bremen, Amsterdam og andre handelscentre i det kornforbrugende Vesteuropa gik gennem Ejderkanalen. I modsat retning gik varer som sukker, frugt, tobak, kaffe og stykgods. Kobberstik 1784, gengivet efter Aage Rasch: Ejderkanalen. 1978.

i de følgende år gang på gang blev dårlig og priserne var høje, måtte tilladelsen til indførsel flere gange forlænges efter indtrængende opfordringer fra lokale øvrigheder.

Det gavnede dog ikke meget. Vinteren 1783-84 blev usædvanlig streng, og nogle steder måtte man på grund af fodermangel bruge stråtagene som foder for husdyrene. ${ }^{96}$ Priserne steg fortsat indtil udgangen af juli $1784,{ }^{97}$ og $\mathrm{i}$ Åbenrå kom det til uroligheder fra skibstømmermændenes og laugenes side, omend der ikke kan siges noget nærmere om arten. ${ }^{98}$

På landet var det flere steder i 1784 svært at skaffe sædekorn, ${ }^{99}$ priserne lå højt, ikke blot her hjemme, men også i Norge og England, og i Tønder klagede laugene i 1786 over ulovligt opkøb af levnedsmidler. ${ }^{100}$

En bedre høst 1787 bragte ikke lavere priser, og atter så de lokale øvrigheder den værste trussel og en væsentlig årsag til problemerne $\mathrm{i}$ korneksporten. I 1787 løb rygterne om store udenlandske rugopkøb på grund af dårlig høst i Østersølandene. Det forlød også, at hollænderne og andre fremmede havde købt store mængder korn i monarkiet. Magistraten i Flensborg talte i den anledning menigmands sag og bad om udførselsforbud for at lette den foregående tids hårde nød. Fra Rendsborg lød det samtidig, at 
der indløb ordrer på tusinder af tønder rug til høj pris fra bl.a. Ostende. Også boghveden blev opkøbt, og magistraten frygtede trods en god høst for dyrtid, hvis der ikke kom et udførselsforbud. ${ }^{101}$ Altså endnu et eksempel på mangel og dyrtid ikke kun p.g.a. misvækst, men også som følge af spekulationsopkøb.

Sammenfattende må 1780 'erne karakteriseres som et årti præget af flere dårlige høstudbytter med mangel og prisstigning til følge. For første gang hører vi nu om, at den menige befolkning selv tog voldsomt til orde og næsten med magt søgte at forhindre, at handelsmænd berøvede dem de sparsomme levnedsmidler. Regeringen søgte i princippet at fastholde importforbud og fri eksport, men måtte gang på gang bøje sig under mangelsituationens krav. Den tidligere så kraftige regulering af kornhandelen var under afvikling, som vi vil se det $i$ det følgende afsnit.

\section{$1789-90$}

Arene 1789-90 hører til de sorte i levevilkårenes historie. 1789-høsten var god, ${ }^{102}$ men alligevel lå priserne ekstremt højt. Det skyldtes atter stærk efterspørgsel fra udlandet og stop for tilførslerne fra Østersølandene, som var ramt af dårlig høst og udførselsforbud. I Frankrig var høsten slået katastrofalt fejl i 1788, og kornmangel og dyrtid bredte sig i 1789. Den franske minister Necker lod opkøbe korn i alle Nord- og Østersøhavne, og det drev priserne i vejret. ${ }^{103}$ I kongeriget næsten fordobledes kornprisen fra 1788 til 1789.

Også i Sønderjylland steg priserne trods frugtbarhed i 1789, »hvorover de fattiges tal, så vel som deres trang, er bleven kiendtlig større“, som det hedder fra Schackenborg. ${ }^{104}$ Derfor lød kravet om eksportstop gang på gang. Det var nemlig opkøbene og eksporten, som trods den gode høst skabte prisstigningen. Magistraten i Flensborg anførte således i november 1789, at høsten havde været god, men alligevel truede dyrtid og mangel. Årsagen var klar. "Alt er hemmeligt og i stilhed opkøbt for hamborgsk og hollandsk regning, delvis før høsten, og af hamborgske købmænd opkøbes der stadig til høj pris." ${ }^{105}$

Sådanne ønsker om eksportstop var imidlertid ikke velsete af regeringen. Netop på dette tidspunkt var liberale handelsprincipper kommet til magten, og i 1788 var en generelt fri kornhandel lovfæstet, uhæmmet af ind- og udførselsbegræsninger. ${ }^{106}$ Man ønskede færrest mulige bånd på handelen. Stillet over for ønsker om et eksportstop for at dæmpe prisernes himmelflugt udtalte regeringen, at landbrugseksporten var livsnerven $i$ hertugdømmernes 
økonomi. Enhver begunstigelse af udførslen af landbrugets produktionsoverskud var til gavn for landet, ethvert indgreb $i$ handelens frie løb burde undgås, når høsten var god. ${ }^{107}$ Kun når det stod helt klart, at prisstigningen skyld tes udførsel, og at en alvorlig mangel faktisk truede, kunne man gribe til et så alvorligt middel som at standse den indbringende eksport. Ud fra denne landbrugsvenlige holdning valgte regeringen at se tiden an. Man forklarede prisstigningen med valutaproblemer og afslog ved udgangen af 1789 ønsker om udførselsforbud, et forbud "som i sig selv ville have en ugunstig indflydelse på statsbalancen. ${ }^{108} \mathrm{Med}$ andre ord: Den begyndende liberalistiske handelspolitik gav ikke megen hjælp under prisstigninger, ja den var et dårligere værn end tidligere tiders handelsrestriktioner. Det syntes, som om kornspekulanterne nu fik frie udfoldelsesmuligheder.

Prisudviklingen for en tønde rug i Tønder 1789-1791

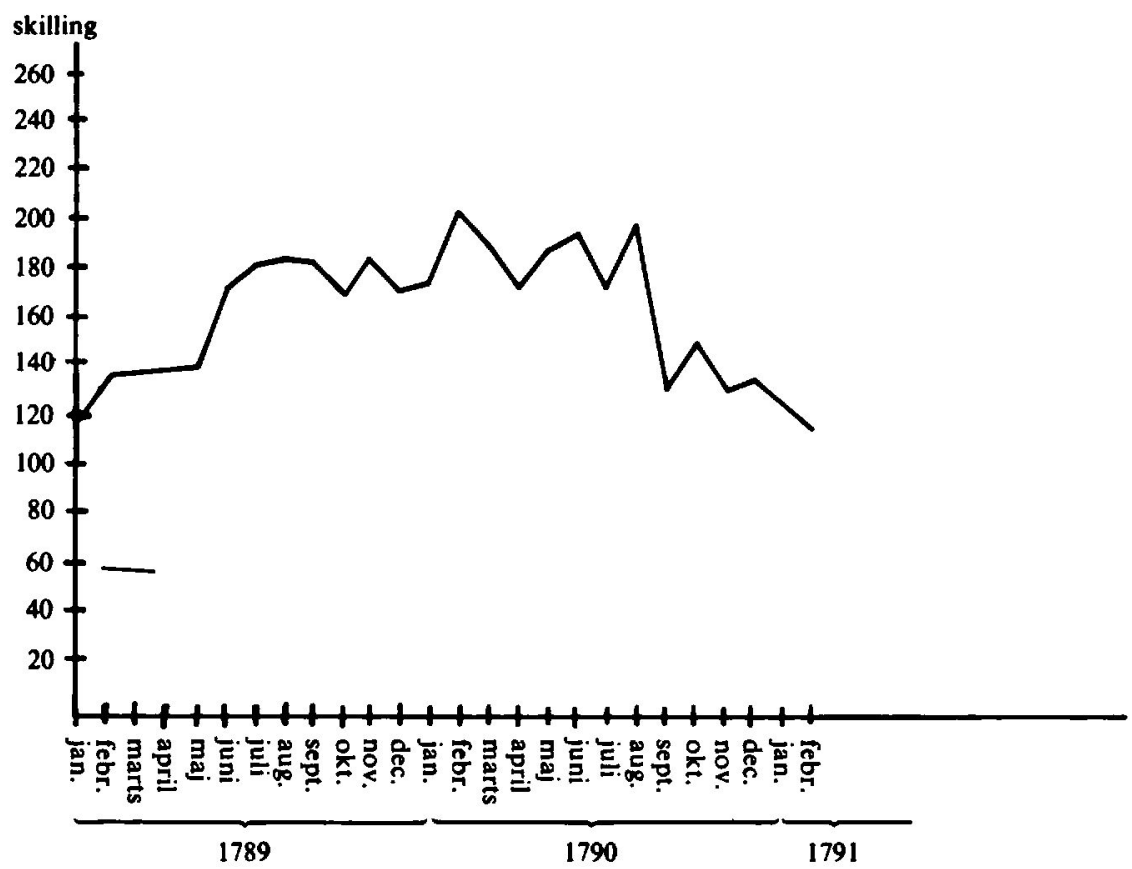

Prisudviklingen for en tende rug $i$ Tender fra 1789 til 1791. Den kraftige prisstigning i sommeren 1789 skyldies poivirkning af mangelen og dyrtiden i udlandet og kraftige opkab. Den gode hast fik $i k k e$ prisen til at falde, og da der ikke blev grebet ind mod eksporten, kulminerede prisstigningen $i$ januar og februar 1790. Resultatet var hungeroptejer $i$ adskillige byer og sogne. Kilde: LA Ab Tender byarkiv, relationsprotokoller. 
Over for denne passivitet mistede befolkningen tålmodigheden. Det skete først på Tønder-kanten, hvor mange jordløse husmænd og inderster så priserne stige samtidig med, at udferslen fortsatte.D. 13. febr. 1790 indfandt nogle hundreder jordløse sig hos greven på Schackenborg og forlangte udførslen af korn forbudt. De fortsatte til Tønder, hvor hen mod 1000 mand atter krævede eksporten standset. Regeringen nedsatte en undersøgelseskommission, og af frygt for uroligheder forbød den faktisk udførslen af rug, men kun for Tønder-egnen, og allerede d. 22/9 $1790 \mathrm{blev}$ forbudet atter hævet. ${ }^{109}$

Også på østkysten var kornudførslen stærk, til skade for den menige forbruger. I februar 1790 klagede borgerne i Sønderborg over, at det vrimlede med fremmede og hjemlige opkøbere på landet. Nyligt havde flensborgske købmænd i Nørreherred opkøbt en hel ladning rug og afskibet den til Flensborg, og en skipper fra Kegnæs lå klar med en ladning til samme by. ${ }^{110}$

I Åbenrå by fandt forbrugernes frygt for det daglige brød dramatisk udtryk lige som på vestkysten. I december 1789 havde magistraten forgæves bedt om udførselsforbud, og snart tilspidsedes situationen. Først på året 1790 indgav samtlige laug en ansøgning om eksportstop, og magistraten støttede atter tanken: prisen var steget, fra Flensborg, Tønder og Vestkysten blev al rug og andet korn opkøbt, og denne stærke udførsel truede med at skabe mangel, så meget mere som import fra Østersøen næppe kunne ventes. ${ }^{\prime \prime \prime}$

Da regeringen tilsyneladende vendte det døve ore til, tog de nødstedte sagen $\mathrm{i}$ egen hånd. $\mathrm{Om}$ formiddagen $\mathrm{d}$. 10. marts mødte representanter for borgerskabet op hos amtmanden på Brundlund for at klage over stigende priser og kornmangel og krævede, at købmand Hans Kopperholt blev forhindret $\mathrm{i}$ at udskibe en ladning rug, han havde liggende på reden. Næsten hele håndværkerstanden og det menige borgerskab stod bag klagerne, og om eftermiddagen mødte hele 60 mand op for at understrege kravets alvor. ${ }^{112}$

Disse optrin viser klart modsætningerne - forbrugerne kontra eksportørerne - og disse modsætninger var ingenlunde begrænset til Åbenrå, Sønderborg og Tønder-egnen. I Flensborg amt klagede kådnerne i Grumtofte over udførslen og bad om et eksportstop. I Skærbæk i Haderslev amt var det 12 inderster, til hvis klage amtmand Rüdiger erkendte, at prisen på rug var steget til 4-4 rdl. 16 skl. pr. td., og næppe var til at få fat på for den pris. Hertil udtalte statholderen, at den kraftige udførsel let kunne skabe mangel, og at et eksportstop derfor var berettiget. Men regeringen fastholdt sin uvilje mod indgreb $\mathrm{i}$ handelens frie løb. Eksportindtægterne måtte ikke røres, og i stedet tillod man, at der af militærets kornforråd kunne leveres korn til trængende byer. ${ }^{113}$

At foråret 1790 var præget af dyrtid og kornkrise, ikke med rod i misvækst, 


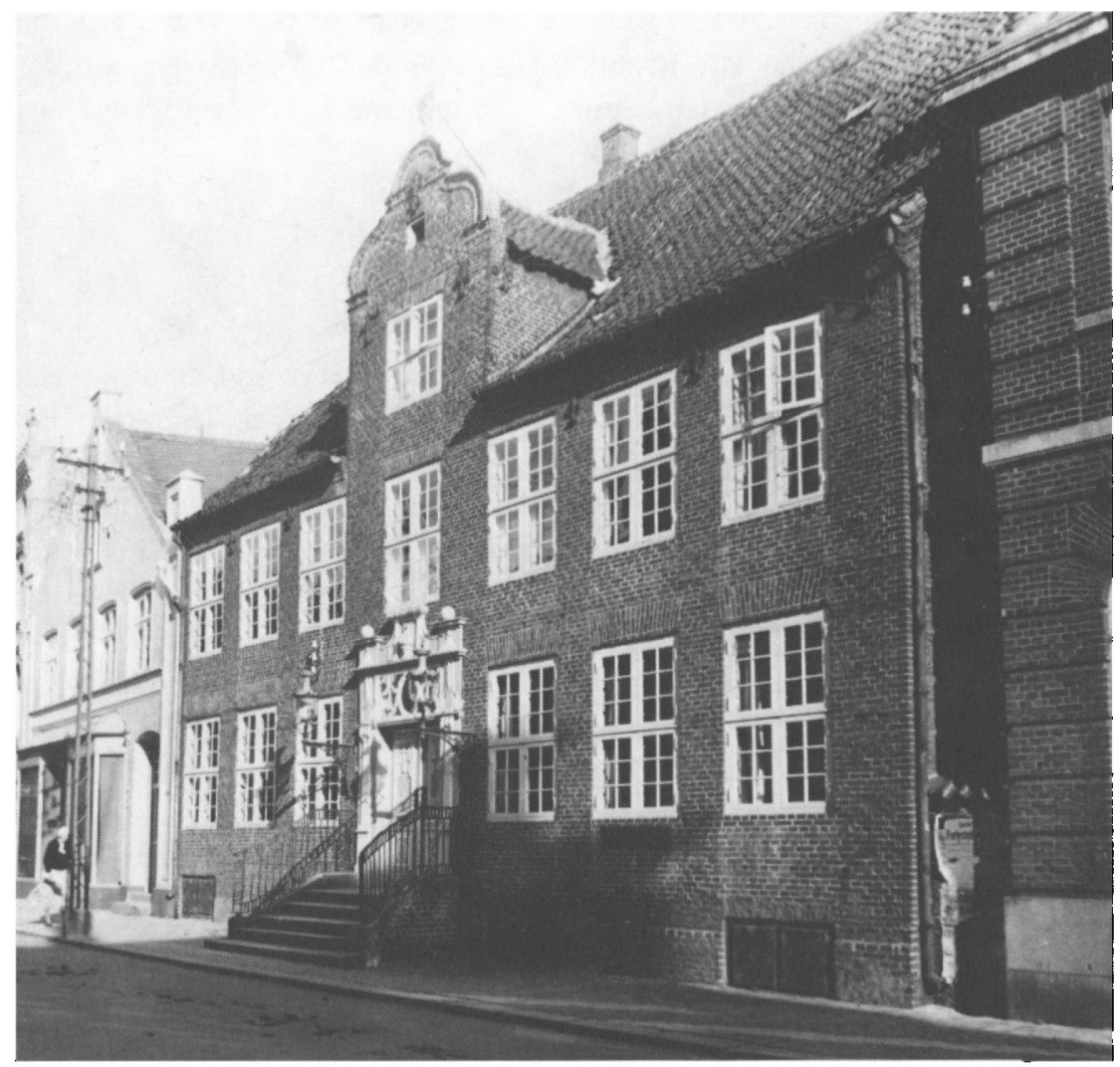

Vestergade $14 i$ Tender, nu Handelsbankens hus, er opfort 1793-94 afkorn, vin-og tobaksgrosserer Hans Jensen Angel, dod 1799. Angel tjente gode penge pd korneksporten og blev derfor i krisedr skydeskive for den oprerte befolknings uvilje. Under den kraftige udforsel og prisstigning i februar 1790 samledes henved 1000 af de utilfredse $i$ Tonder og kravede udforslen stoppet. De angreb bl.a. Angel for at ville eksportere en ladning korn til Bordeaux til betaling af en ladning vin. For at dampe uroen fik amtmand Bertouch Angel til at undlade eksporten og istedet tilbyde de utilfredse kornet til moderat pris. Demonstranterne fandt den dog for hoj, og Angel har nappe heller lidt tab. Hans smukke ejendom med den pragtfulde Louis Seize dor viser, at kebmandens økonomi var sardeles velkonsolideret. (Historiske Samlinger for Senderjylland).

men i spekulation og eksport, påvirket af udenrigspolitiske forhold og kornmangel i udlandet, er der herefter næppe tvivl om. $\mathrm{Og}$ i denne nødsituation fandt forbrugerne ikke megen støtte. Den begyndende liberalisme, som tjente producenternes og de handlendes krav, kom let på tværs af forbrugernes interesser. Liberalismen var nu knæsat af regeringen. Få år senere, i 1795, kom disse frihandelstanker imidlertid atter på en hård prøve, en så hård prøve, at regeringen måtte gå på akkord. 
Det er også bemærkelsesværdigt, at underklassen, på hvem byrderne hvilede hårdest, nu søgte at tage retten $\mathrm{i}$ egen hånd. Den passivitet, som ses før 1780'erne, og den begyndende protest, som mærkes i 1782 og 1784, blev i 1789-90 afløst af åben handling.

\section{$1795-96$}

Året 1795 blev kritisk over hele Europa. Høsten i 1794 mislykkedes i mange lande, og dyrtid og mangel blev resultatet. Regeringerne greb til udførselsforbud, og i by og på land måtte der indtil høsten 1795 sørges for brøduddeling til ubemidlede. ${ }^{114}$

I Sønderjylland hørte høsten i 1794 ikke til de dårlige, men stod dog ikke mål med efterspørgslen. De sædvanlige tilførsler fra Østersøen og Hannover udeblev, og fra Holland, som var ribbet for korn af franskmændene, skete der store opkøb i udlandet. Det måtte selvfølgelig påvirke kornmarkedet i Slesvig og Holsten, hvortil mange mennesker tilmed var flygtet for krigsuro og

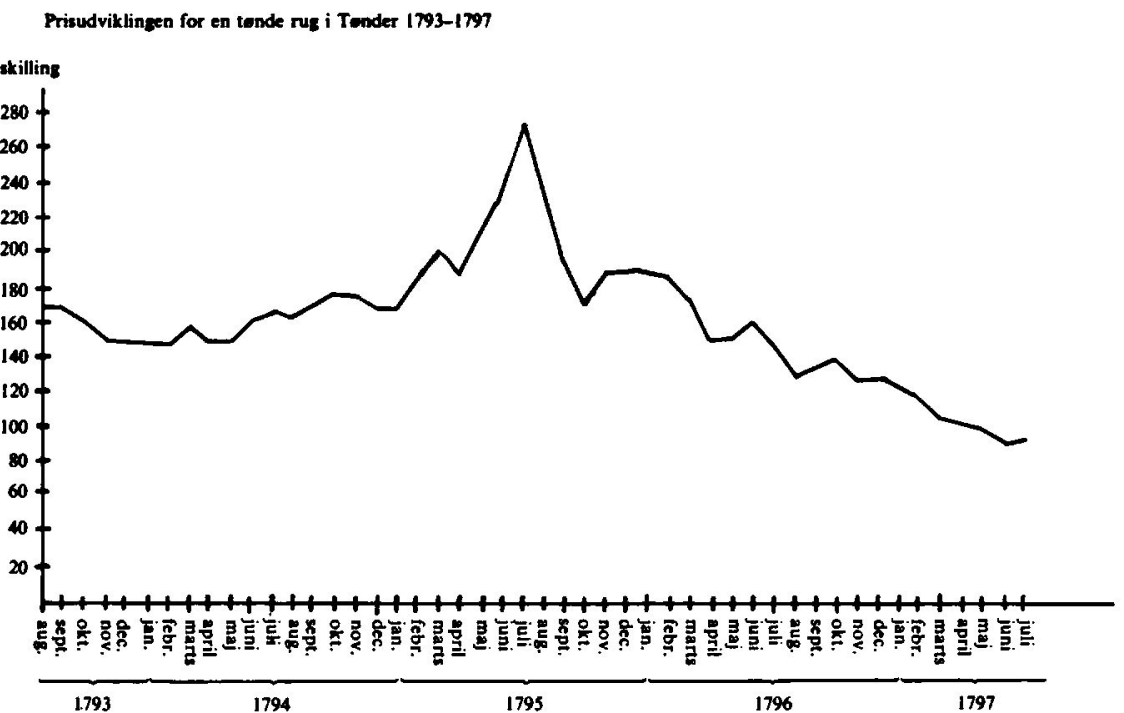

Prisudviklingen for en tonde rug $i$ Tender fra 1793 til 1797. Den kraftige prisstigning i foraret 1795 skyldtes isar opkeb, og udforselsforbudet af 6. marts 1795 skabte kun en kortvarig afbrydelse $i$ prisernes himmelflugt. I juni og juli 1795 toppede krisen, og netop pd dette tidspunkt pragede hungeruro byer som Flensborg, Sonderborg og Haderslev. Den gode host $i 1795$ fik priserne til at falde, men isar $i$ Holsten varede vanskelighederne ved. Kilde: $L A$ Ab Tonder byarkiv relationsprotokoller. 
revolution. Følgen var øget forbrug, mangel og prisstigninger. I det tidlige forår 1795 bad flere byer i Holsten, som var mest udsat for de fremmede opkøb (Altona, Kiel og Rendsborg), om udførselsforbud. ${ }^{115}$ Regeringen kom i et dilemma. Hvordan skulle man stille sig til sådanne ønsker, som brød med den frihandelspolitik, som var knæsat siden 1788 ?

Udviklingen gav svaret. Korneksporten tog et foruroligende omfang. Priserne steg til højder, som faldt tungt for alle arbejdsfolk, og som truede med at skabe mangel. Problemernes vægt tvang regeringen til at tage parti for den ubemidlede forbruger. Når udførslen i den grad truede med at skabe mangel, "var det rådeligt at indskrænke den enkeltes frihed af hensyn til det almenes vel «, og den forbød derfor d. 6. marts 1795 al kornudførsel indtil 1. september og indførte samtidig bestemmelser til begunstigelse af importen. Også kartofler var indbefattet $i$ forbudet, et bevis på denne afgrødes nyvundne betydning.

Alligevel fortsatte prisstigningerne, og de divergerende interesser måtte nødvendigvis støde sammen. I Tønder frygtede de deputerede og samtlige laug først i marts dyrtid og kornmangel og bad om modforholdsregler. Kornhandlerne protesterede: de bagatelliserede klagen som et ubetimeligt (utidigt) spektakel (Lärmblassen) og fremhævede, at den frie kornhandel ikke burde forstyrres. Magistraten, som skulle se på hele byens fælles interesse, vidste noget andet. Den fremhævede, at bønder og borgere på provision købte korn op til Husum, og at udsendinge fra nær og fjern samlede korn med henblik på udskibning fra Højer, Ballum, Emmerlev, ladepladsen Sydvesthjørne i Emmelsbøl sogn og Feddershof i Dagebøl kog. Mangel og prisstigning måtte blive følgen, og derfor måtte man undtagelsesvis bryde med den frie kornhandel. Eller med magistratens egne ord: "Vi er enige med kornhandlerne $i$ at den frie kornhandel $i$ reglen ikke bør forstyrres. Men når rugen udføres så stærkt, at priserne stiger, bør der her ske en undtagelse. Ganske vist drager kornhandelen penge til landet, men den beriger dog især kun dem, som driver denne handel, og tallet af dem, som vinder ved den stærke udførsel kan ikke sammenlignes med antallet af de undersåtter, for hvem det slet ikke kan være ligegyldigt, om de skal købe de uundværlige livsfornødenheder til en rimelig eller en overdrevent dyr pris. Selv om kornhandelen drager millioner til fra udlandet, er den fordærvelig, når den lægger et tryk på de uformuende, som altid er flest, og som kan bære den ringeste byrde, dvs. når den medfører mangel eller urimelig fordyrelse af brødkornet. Thi for den uformuende, som må ernære sin ofte talrige familie udelukkende ved sine hænders arbejde, er en overordentlig prisstigning på brødkorn det samme som fuldstændig mangel, fordi hans arbejde ikke kaster nok af sig til at han kan købe det enormt dyre brødkorn, og han har ingen 
kredit så han foreløbig uden penge kan erhverve denne uundværlige livsfornødenhed. ." ${ }^{16}$

Skildringen opridser modsætninger, som snart slog ud i lys lue. I maj måned lod 300-500 digearbejdere ved Okholm i Bredsted amt fire skibe, som skulle sejle til Altona, gennemsøge, idet de troede, at de var ladet med rug til eksport. De tvang en kornhandler til at sælge over 100 tønder for 4 rdl. pr. td. ${ }^{117}$

Priserne fortsatte med at stige, og amtmanden i Tønder måtte købe rug op af hensyn til digearbejderne. ${ }^{118}$ Regeringen blev bestormet med meddelelser om, at rug blev opkøbt og lagt på lager i den tro, at udførslen atter ville blive tilladt, og at der skete ulovlig udførsel via Altona. ${ }^{119}$ For at hindre denne udførsel blev byfoged Kröger i Altona antaget til hver nat at lade Elben patruljere, så ingen kunne slippe bort med kornladninger. ${ }^{120}$

Magistraten i Sønderborg harcellerede allerede i marts over, at fremmede rejste rundt på Sydals for at købe op og eksportere, og den krævede, at lagrene blev konfiskeret og solgt i småportioner i Sønderborg. ${ }^{121}$ Fra Løgumkloster berettede amtsforvalter Lucas i begyndelsen af juni, at opkøb selv hos de større bønder, som normalt havde et overskud til salg, havde decimeret forrådet, så der næppe var tilstrækkeligt til husholdningen. ${ }^{122}$

I Flensborg forlød det $\mathrm{i}$ begyndelsen af juni, at de sidste $2000 \mathrm{td}$. da blev afskibet fra Sønderborg til Altona, og at alle forråd i Jylland var opkøbt af kornhandlere. ${ }^{123}$ Det var foruroligende. Mangelen tog til, priserne steg, og det gærede $\mathrm{i}$ befolkningen. Magistraten anede uråd, og anmodede tidligt d. 1 . juni om, at militærgarnisonen måtte blive $\mathrm{i}$ byen. Frygten var berettiget, og pludselig kom det ventede udbrud af utilfredshed.

Skibstømrerne og daglejerne krævede samme dag brød i stedet for penge, og samlede sig i protest mod de høje priser. Magistraten havde allerede tidligere gennem kornopkøb søgt at modarbejde de store prisstigninger. Nu tvang "oprørerne « nogle købmand til at sælge til lavere pris. Magistraten lod som modtræk garnisonen trække op, og det beroligede for en tid gemytterne. Samtidig fandt man det dog nødvendigt at bede om yderligere militærforstærkning.

Dagen efter, d. 2. juni, lod magistraten på opfordring af statholderen og i betragtning af det utilstrækkelige kornforråd bekendtgøre, at ingen købmand måtte sælge til fremmede af sit forråd, men at det skulle overlades

For at berolige de ophidsede gemytter, som af frygt for hungersned truede med åbent oprer, mátte magistraten i Flensborg d. 2. juni 1795 udstede denne plakat, som bl.a. påbed kornhandlerne at salge korn til smáfolk til fast pris (RA Statholderskabet pk. 7,2). 


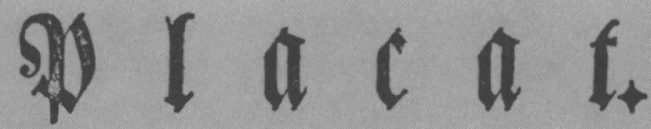

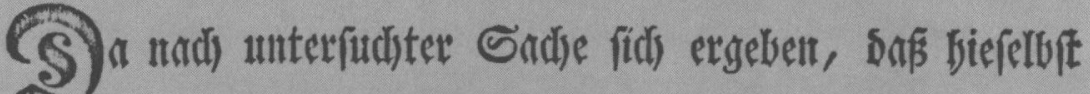

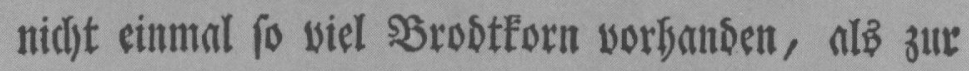

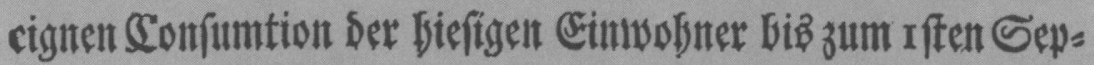

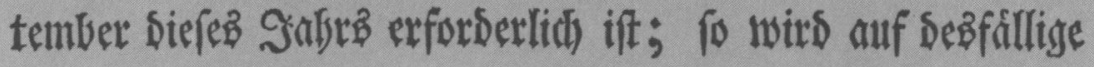

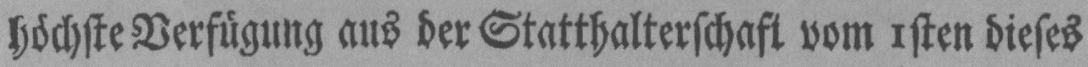

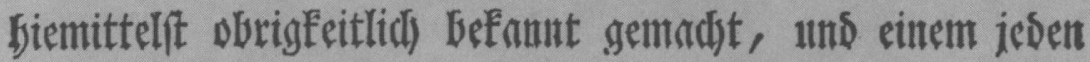

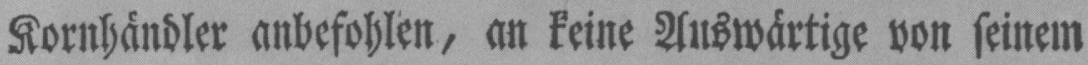

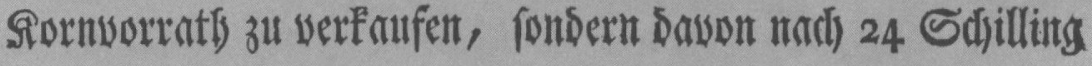

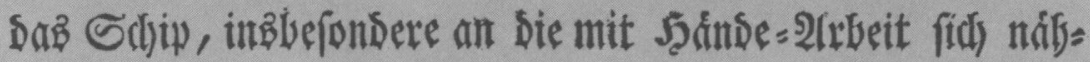
rende Einubobner, J5antwerfer, Tangeldbiner und Dergleidjen,

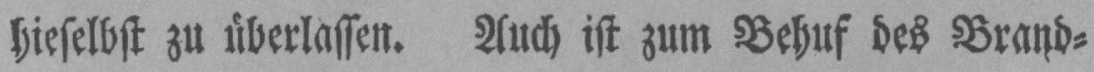

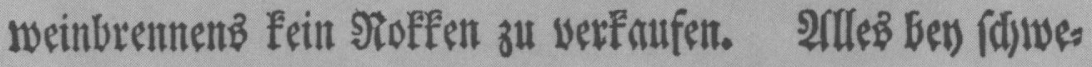
rer Strafe unts 2lfntoututg.

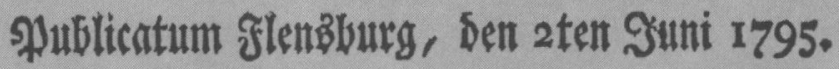

Bingermeiftere und Stath bicfelbff. 


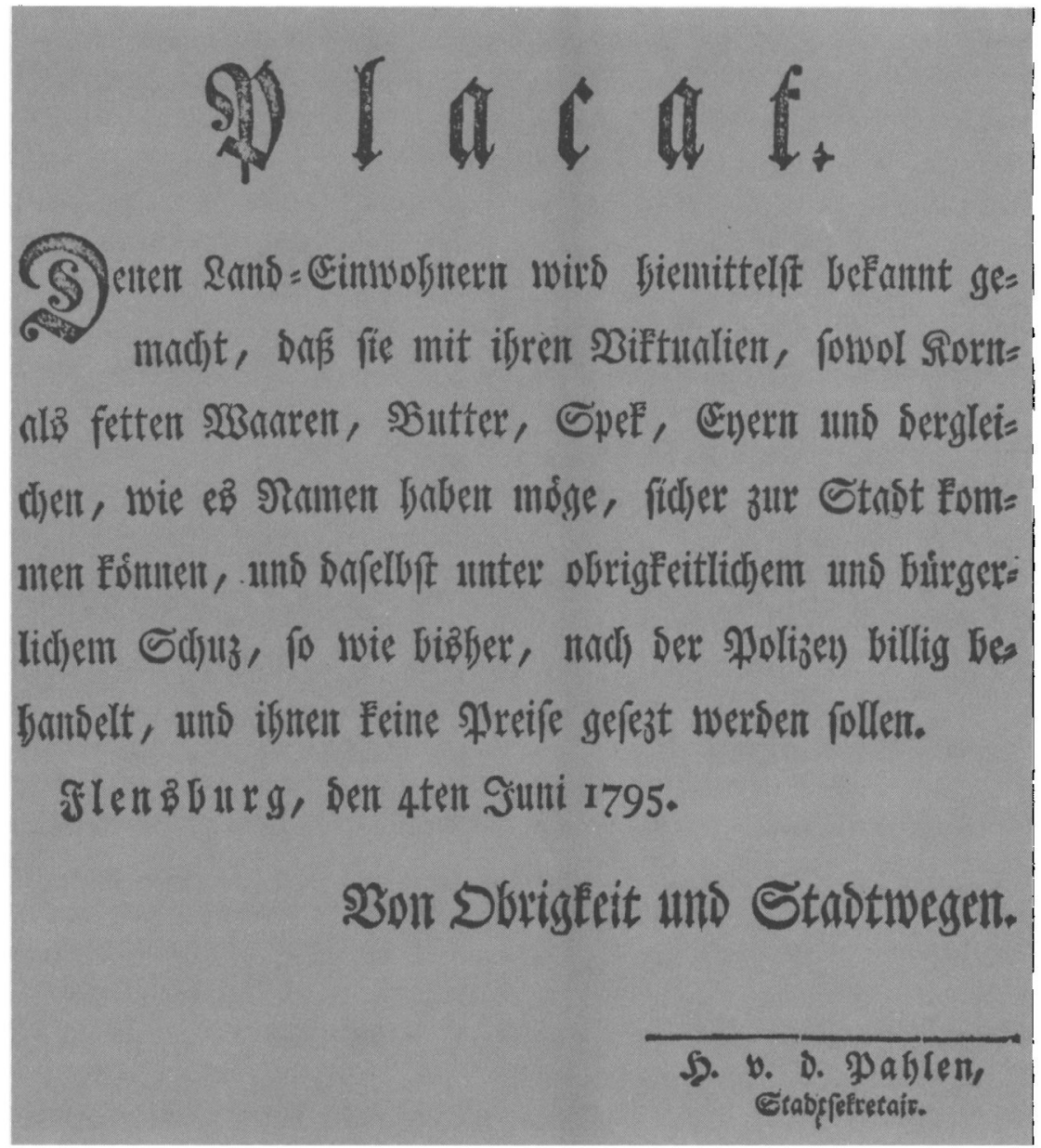

Uroen blandt den javne bybefolkning i Flensborg skramte i juni 1795 bonderne i omegnen bort fra markedet af frygt for at blive udsat for overlast og pristryk. For at lokke dem til byen med de livsnodvendige forsyninger udsendte ovrigheden derfor d. 4. juni denne forsikring om beskyttelse (RA Statholderskabet pk. 7,2).

byens egne børn, især de ubemidlede, for 24 skl. pr. skp. Rug måtte heller ikke sælges til brændevinsbrænding. Plakaten gjorde god virkning, og tilsyneladende lod folk sig berolige.

Dog kun kort. Den 4. juni så øvrigheden sig i „den mest påtrængende fare«, idet "antallet af oprørere er utrolig stort«. Uroen var udsprunget af den katastrofale kornmangel. Folks krav om maksimalpris og den spændte 
situation skræmte tilmed bønderne fra byen, så det $\mathrm{d}$. 4 . juni blev nødvendigt at udsende en plakat til bønderne om, at de ikke ville blive udsat for faste priser eller uroligheder ved at komme til byen. Næsten panikslagen mente magistraten det også samme dag nødvendigt at bede om størst mulig militærforstærkning. Ufortøvet sendte statholderen et betydeligt militærkorps til byen, og det lykkedes at skabe ro. Et efterspil fik sagen også, idet der blev foretaget arrestationer og 10 personer blev idømt straffe på 1-8 års fængsel. ${ }^{124}$

Episoden viser situationens alvor og den illustrerer modsætningen mellem forbruger og købmandsstand. At befolkningens desperation var berettiget, ses når man betragter priskurven side 34 .

Fra Flensborg bredte rygtet om "hungeropløbet" sig til Sønderborgegnen. I Hørup sogn gik synsmændene d. 3. juni 1795 "omkring hos hver mand for at optegne hvor meget korn de havde i forråd for at afværge en muelig trang. ${ }^{86}$

I Sønderborg by satte kornkrisen dybere spor. Her havde magistraten tidligere henstillet til købmændene at sælge korn til moderat pris og at tage særligt hensyn til de fattige, efter eget sigende med noget held. Pris- og forsyningssituationen var dog fortsat kritisk, og da en skipper fra Arnæs d. 6. juni havde indskibet $180 \mathrm{td}$. rug for at sejle til København, blev det for meget for den ubemidlede forbruger. 60 tømrere fra skibsværfterne samlede sig $\mathrm{i}$ protest på skibbroen, hvorfra de gik til den fungerende borgmesters hus. Fire talsmænd gav her udtryk for frygt for mangel og dyrtid.

Opløbet var jo en truende manifestation af utilfredsheden, som gjorde bystyret bange. Men det lykkedes at ride stormen af. Borgmesteren erklærede at ville hjælpe, hvis forsamlingen spredtes roligt. Det lod skibstømrerne sig nøje med, og til gengæld fik magistraten i den kommende tid købmændene til at love at holde et kornforråd $\mathrm{i}$ beredskab indtil næste høst samt at sælge til fattige for moderat pris. ${ }^{125}$

Også i Haderslev kom det på samme tid til tumultagtige optrin på grund af de høje kornpriser. ${ }^{126}$ Dette kunne sammen med urolighederne på vestkysten, i Flensborg og i Sønderborg ikke undgå at gøre indtryk på myndighederne. De indkrævede oplysninger om de lokale kornforråd og indskærpede udførselsforbudet. D. 17. juni opfordrede statholderen magistraterne til at organisere salg af billig rug til fattige og ubemidlede håndværkere og daglejere. $^{127}$

Ideen blev praktiseret rundt omkring. I Tønder lod magistraten opkøbe 100 td. rug på byens regning med henblik på videre salg i småportioner til fattige og ubemidlede håndværkere og daglejere for $12 \mathrm{mk}$. pr. tønde, $2 \mathrm{mk}$. 6. skl. under dagspris. Men det var vanskeligt at skaffe de $100 \mathrm{td}$. Trods det at 
to deputerede rejste rundt i amtet, havde de efter nogen tid kun skaffet $45 \mathrm{td}$., og de opdagede f.eks., at en købmand Cosmus fra Husum i Ravsted havde købt næsten 60 td. rug til oplagring indtil udforsel atter blev tilladt. Via amtet opnåede man, at rugen blev lagt under arrest og udførsel forhindret. Samtidig forbød man kornhandlerne at sælge til fremmede, og de fik pålæg om at bringe korn indkøbt på landet til salg på det offentlige marked $\mathrm{i}$ Tønder. ${ }^{128}$

I Ábenrå besluttede magistraten ligeledes efter nogen tøven at indkøbe rug på byens regning for at begrænse prisstigningen og hindre mangel på brødkorn. D. 3. juli bekendtgjorde man, at indbyggerne, som indtil høst ikke kunne få korn på anden måde, kunne henvende sig hver torsdag til købmand Jacob Frederik Bjørnsen. Den følgende lørdag ville de derpå få leveret rugmel til en moderat pris af 32 skl. pr. skæppe. Udgifterne ved denne hjælpeforanstaltning blev dækket af byens kasse. ${ }^{129}$

Indtil slutningen af juli måned fortsatte kornpriserne med at stige. Man mente det skyldtes, at købmænd og bønder fortsat købte korn op eller holdt det tilbage, med andre ord spekulerede $i$ en snarlig genåbning af den fri udførsel. Også den standsede udførsel fra Østersølandene gjorde sig gældende. Regeringen måtte derfor d. 3. juli forlænge forbudet indtil d. 1. dec. ${ }^{65}$

Mod al forventning lettede det kun lidt på problemerne, og heller ikke en meget stor høst bedrede situationen. Klagerne fortsatte, særlig grelt fra Holsten, og forbruger og producent kappedes om at vinde regeringens gunst. Landbrugsinteresserne, især i Nord- og Sydditmarsken, fremhævede, at eksport hentede valuta til landet og stimulerede til produktionsforøgelse, mens forbud svækkede bøndernes indtjening og skatteevne. Frihandel kombineret med kornmagasiner til sikring af de fattiges kornbehov var langt at foretrække. ${ }^{130}$ Fra byerne lød tonerne helt anderledes, og alt tyder på at vanskelighederne i Holsten, under påvirkning af kornaftageren $\mathrm{H}$ amborgs nærhed, faktisk var særlig alvorlige. Flækken Ütersen fremhævede, at kornspærringen i udlandet, sammen med krigsforholdene, Hamborgs nærhed og troen på, at eksport ville blive tilladt efter 1. dec., fik rige købmænd til at købe korn op "for $i$ udlandet at nyde det rige udbytte af deres spekulationer omend på bekostning af udtærede og udhungrede medmennesker«. Virkningen af disse spekulationer blev særlig alvorlig, da mange bønder efter gode indtægter de foregående år undlod at sælge deres høst og i stedet lagde kornet på lager i håb om endnu højere priser. Fra magistraten i Plön lød ligeledes kravet om forlængelse af udførselsforbudet. Allerede nu kunne arbejdsfolk, selv når de havde arbejde, ikke ernære kone og børn, og langt mindre skaffe brændsel og varme. Bystyret kunne ikke få sine skatter og fattigdom med røveri og tyveri blev følgen. Fra Glückstadt klagede en kopist Detlevs i oktober over, at kornkøbmænd opkøbte korn til uhyrlige priser. De solgte 
nødig igen, og da kun med stor fortjeneste. Brændsel og kød blev udskibet $\mathrm{i}$ stor mængde, og den gode høst var det således kun købmænd og bønder, som drog fordel af. ${ }^{131}$

Såvel statholderen og lokalregeringen i Glückstadt som rentekammeret i København lod sig overbevise. Statholderen udtalte d. 11. juli: I tidligere tider var det misvækst, som skabte dyrtid, og befolkningen havde derfor roligt bøjet sig under åget. Men nu var det handelsspekulationer, som var synderen. $\mathrm{Og}$ han fortsatte: "Når fordyrelse af en livsfornødenhed, som er høstet $\mathrm{i}$ overflod $\mathrm{i}$ landet, opstår alene p.g.a. købmænds handelsspekulationer, og den fattige undersåt ser sig udsat for en vilkårlig behandling fra sin bemidlede medborger, hvis velstand han som regel må misunde, så anser han sig for berettiget til højlydt misfornøjelse og hvem kan på forhånd beregne følgerne deraf? ${ }^{131}$ Fra Glückstadt udtrykte regeringen ligeledes d. 9. okt. folkets opfattelse, nemlig at dyrtiden og dens beklagelige følger alene skyldtes nogle få handelsmænds vindesyge. Høsten havde været stor, og forrådet var betydeligt, men det vældige opkøb skabte alligevel priser som i misvækstår. Kollegiet var overbevist om, "at der under kongens lykkelige og viise regering ikke tænkes på indre uro, med mindre hunger og mangel under denne uhørte dyrtid skulle fremkalde overilede, men derved farlige skridt fra de nødlidende. Det er netop dette som ifølge gentagne rygter må frygtes fra denne klasses side, og det ville især ytre sig mod de få handelsfolk, som vinder så overordentligt derved. “131 Rentekammeret i København bakkede lokalregeringen op og foreslog udførselsforbud: "Alle de fordele som den fri kornhandel kan give en handelsnation, den mængde af klingende mønt, som kan drages til landet og den derved øgede erhvervsflid, kan over for frygten for en virkelig mangel og en altfor stor dyrtid og de sørgelige følger deraf ikke komme i betragtning.“ Kun nogle få købmænd og godsejere ville vinde ved en fri handel, byborgerne og alle fattige ville tabe derved. Hvor hårdt det end var at berøve landmanden den fri afsætning af overskudsproduktionen, så fandt rentekammeret det dog billigt at beskytte forbrugerne mod dyrtid og hindre, at nogle trods overflod måtte lide hunger. Kollegiet måtte derfor foreslå et udførselsforbud på ubestemt tid. ${ }^{132}$ Kongen fulgte indstillingen d. 4. nov.; det viser, hvor skræmt regeringen var over situationen, og at frygten for uroligheder, ja revolution, var reel i hele administrationen. Derfor måtte man bryde med frihandelsprincipperne.

Beslutningen af 4. nov. medforte dog ikke straks lavere priser, og modsætningerne fortsatte. Rentekammeret udtalte d. 6. febr. 1796, at ønsket om forbudets ophævelse var enstemmigt hos dem, som ikke mente at kunne sælge overskuddet af deres gode høst dyrt nok, og hos spekulerende kornhandlere, som søgte at berige sig under de nærværende konjunkturer. 
Derimod ønskedes forbudet bevaret og overholdt af dem, som måtte købe korn, og som sukkede under de dyre priser. Kollegiet var ikke i tvivl om, at landmanden fik en så stor gevinst af priserne, at der ikke var nogensomhelst grund til at ophæve forbudet. Tværtimod skulle vindesyge spekulanters kneb modarbejdes på bedste vis. ${ }^{133}$

Trods alt bedredes forholdene, og d. 20 . maj 1796 fandt man det atter forsvarligt at ophæve forbudet af 4. nov. 1795. Den værste krise var overstået. Den var skabt ikke af misvækst, men af for stor eksport og kornspekulation og havde vist, at regeringen i en nødsituation trods frihandelsideologien indså en regulerings nødvendighed og havde den brede befolknings bedste for øje. Men det må antages, at denne ansvarsbevidsthed snarere var fremtvunget af frygt for uroligheder $i$ underklassen end af ideelle motiver. Det var erfaringen fra den franske revolution, som spøgte $i$ underbevidstheden.

\section{9-1801}

De følgende år var kornpriserne betydeligt lavere, og udførslen derfor frigivet. Men i Flensborg turde man dog efter uroen i 1795 ikke risikere noget. Både i 1796 og 1797 indkøbte byen korn for at hindre uro, og det blev solgt ved offentlig auktion. I 1798 og 1799 lod man for at være sikker på tilstrækkelige forråd borgerne forpligte sig til at gemme et vist kvantum korn, som om nødvendigt skulle sælges til dagspris efter magistratens ordre. ${ }^{134}$

Men så kom året 1799. Vinteren 1798-99 var hård og store snemængder hindrede gennem lange tider færdsel og næring. ${ }^{135}$ Den følgende sommer 1799 var kold og fugtig, og høsten blev sen og under middel. Priserne steg, forrådet af korn var beskedent, og tilførslerne svigtede på grund af udførselsforbud i Rusland og ved Østersøen. Samtidig optrådte England som storopkøber af korn, og meget korn blev eksporteret til Hamborg og videre vestpå. Byer som Glückstadt $\mathrm{og}$ Rendsborg frygtede for forsyningerne $\mathrm{og}$ bad derfor om et udførselsforbud. ${ }^{136} \mathrm{Da}$ også vinteren $1799-1800$ blev hård, sommeren næsten udeblev og høsten mislykkedes, forværredes forholdene, og prisernes bratte stigning fortsatte. Bondeskipperen Søren N. Rasch fra Ho sogn ved Blåvandshuk berettede $\mathrm{i}$ sine optegnelser: „På sine steder (stod) sæden ude midt i okt. (1799), vintersæden nedsølet $i$ jorden og foranledigede det næste års slette høst på rug og hvede især og høje priser, så landet ej kunne forsyne sig selv, men måtte hente udenrigs fra, der forårsagede dyre tider. . ${ }^{137}$

Fra den modsatte kyst, fra Hørup på Als, læser man i nogle optegnelser: "Til den tid (1800) var priserne: 1 pd. smør $81 / 2$ skl., og en skæppe rug 2 mk. 4 skl. som er $18 \mathrm{mk}$ for tønden, men kort derefter købte Jørgen Paradis i 
Prisudviklingen for en tende rug i Tender 1799-1802

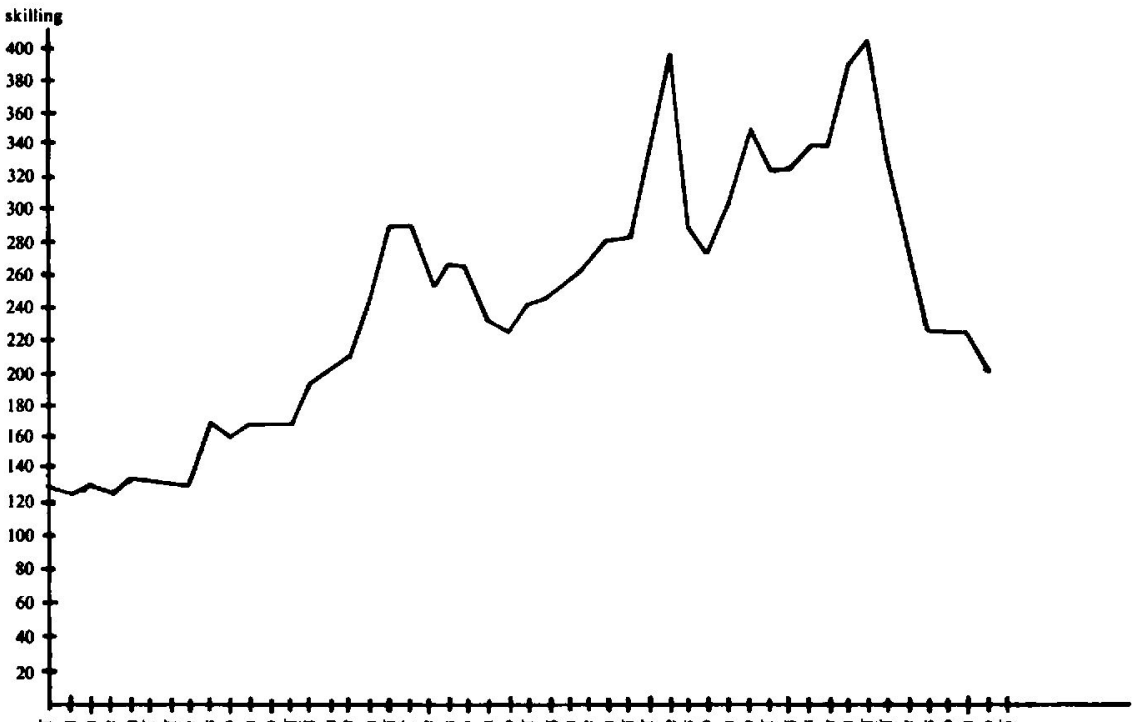

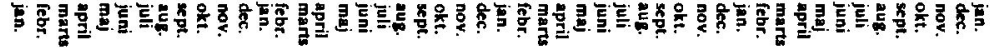

1798

1799

1800

1801

1802

Prisudviklingen for en tonde rug $i$ Tonder 1798-1802. Manglende tilforsler fra udlandet og starke opkeb skabte i 1799 prisstigningen, og hesten beted kun en vis stagnation. Priskurven fortsatte opad mod kulminationen i august 1800, da udforslen blev forbudt. Forst den gode host $i 1801$ fik endeligt prisen til at falde. I ovrigt ligger de hojeste priser i tiden lige for den nye host, et typisk forlab. Kilde: LA Ab Tonder bys relationsprotokoller.

Majbøl 1 tønde rug i Sønderborg hos Chr. Karberg for $22 \mathrm{mk} .$, en meget høj pris." ${ }^{86}$

Prisstigningen og krigen $\mathrm{i}$ udlandet foruroligede regeringen, $\mathrm{i}$ Norge var kornmangelen akut, og d. 1. aug. 1800 blev kornudførsel forbudt. ${ }^{65}$ Samtidig forbød man brændevinsbrænding af rug. ${ }^{138}$

Forbudet i sig selv klarede dog ikke problemet. Magistraten i Flensborg lod anlægge et kornmagasin for at sikre indbyggerne mod hungersnød. ${ }^{139} \mathrm{I}$ Åbenrå organiserede byen kommunalt salg af rug, ${ }^{140}$ og i nov. fik de høje priser nogle til at frygte brødmangel, ja hungersnød for håndværkere, daglejere og gamle og fattige. En konferensråd v. Zülow tilbød at øge sin skattebetaling for at byen kunne få råd til at formidle billigt kornsalg, ${ }^{140} \mathrm{og}$ under ledelse af pastor Nissen foretog man husindsamling og uddeling af suppe til fattige. ${ }^{141}$

Forbudet mod rugeksport betød et vist prisfald, men mangelen fortsatte, dels på grund af svigtende tilførsel, dels på grund af ulovlig udførsel, og fordi 
bønderne i spekulationsøjemed holdt kornet tilbage. På Tønder-kanten fandt forbrugernes nød markant udtryk. Høsten havde været så ringe, at ikke blot husmænd og andre, men også bønderne måtte frygte for husholdnings- og sædekorn. Modsætningen til en af storproducenterne, Bendix Holst på Trøjborg, tilspidsedes i de små hjem, og i dec. 1800 blev sedler af følgende indhold hængt op på dørene i Tønder amt og enklavesognene:

\section{Gode Venner allesammen.}

Efterdi I samt og vi lider stor Nød og Mangel paa Korn, Smør samt meer, det skeer af den Aarsag, at di forbandede Mennesker, som køber det meget Korn at feede deres Stude med samt og at skibe det, Udskiben angaar die store Korn Puger i Tønder og andre adskillige meere, og di, som fede deres Stude dermed, er navnlig Cancellie Raad Holst paa Troyborg, Hr. Detlefsen i Ballum samt og adskillige Bønder i Ballum Sogn, hvilke foraarsager den forskrækelig dyre Tid, og om det skal saa beholde denne Fortgang, saa bliver i det nye Aar aldrig en Skippe tilkiøbs, derfor maa forfindes Raad, før det bliver for silde, ellers maae vi alle med hinanden ynkelig omkomme af Hunger og Nød. Det er det, at disse grove Bloodhunde tragter efter, derfor giøre eder reede allesammen ingen undtagne, som er istand til at udrage noget Gewærd ligegodt hvad heller det er Flint, Økse eller Stav og mødde ved Trøjborg præcis den 5. December 1800 . Vester-Jylland...

Tilsiges alle samtlige Kaadner og Lejefolk, at møde ved Trøjborg alle Mandfolk, ingen understaar sig at blive hjemme heller ikke at komme barhaandet, men beruste sig dog ikke at skade nogen Mands Liv, men sine fede Stude og Bygninger og det den 5te Septbr. (!) fra Nabo til anden i Sønder og Nør-Sejersleff. Cito licto at besørge.

På samme måde klagede kådnere og inderster i Hjerpsted sogn over de store bønders studefedning, hvorved kornpriserne blev drevet i vejret. De ønskede indgreb mod spekulationshandel og ønskede anlagt kornmagasiner, hvorfra der kunne udleveres korn i en dyrtid. ${ }^{142}$

Disse eksempler fra Tønder-egnen bekræfter den århundredgamle problematik, men en ny tid havde gjort de klagende mere velformulerede og dristige.

Det beskedne prisfald som ledsagede udførselsforbudet af 1 . august hjalp ikke meget, for i stedet kastede opkøberne sig over kartofler og fedtstoffer, især smør. Smørprisen tredobledes, og fronterne blev på ny markeret. Priserne ramte især byerne, og fra en hel række magistrater (Ütersen, Heide, Burg, Itzehoe, Glückstadt, Plön, Oldesloe, Krempe) hævede sig kraftige anklager mod landmænd og opkøbere: bønderne havde tjent fedt på de gode 
priser, og var blevet rige på byernes bekostning. De havde nu råd til at holde varerne tilbage, og smør blev eksporteret så vildt, at der nu snart kun var det tørre brød tilbage for småfolk i byerne. Brændevinsbrænderne derimod bad om at måtte fortsætte deres næring, uden hvilken f.eks. daglejere ville miste den drik, som sammen med det tørre brød i disse dyrtider næsten var det eneste, som kunne gengive dem kræfter efter arbejde. Det store kvæghold blev også umuligt, når brændingen lå stille, til skade for forsyningen med mælk og kød. De kornproducerende egne ved vestkysten (Pellworm, Før) bad om at måtte udføre korn. Men regeringen stod fast på forbrugernes side og indskærpede d. 21. okt. 1800, at der ikke kunne lempes på forbudene; så længe priserne var så høje kunne der ikke gives indrømmelser, og alle embedsmænd fik pålæg om at forhindre, at vindesyge spekulanter omgik forbudene. ${ }^{143}$

Denne standhaftighed var berettiget, for få dage efter kunne amtmand v. Schmettau i Åbenrå takke for bestemmelsen og tilføje, at smørret var steget på grund af opkøb og udførsel, til skade for småfolk, for hvem brød og fedtstof var et uundværligt næringsmiddel. Amtmand v. Bertouch i Tønder bekræftede samtidig, at ulovligt opkøb og udførsel faktisk gik i svang i Tønder og ved vestkysten. ${ }^{144}$ Det var derfor berettiget, at kartoffeludførsel blev forbudt d. 7. nov. og opkøb af smør d. 5. dec.

Frygten rundt om $\mathrm{i}$ byerne kunne dog ikke forsvinde blot på grund af regeringens velvilje. I Flensborg sendte man derfor for at forebygge hungersnød et skib til Wismar for at hente rug til brødkorn. ${ }^{145}$ I $\AA$ benrå var deputeretkollegiet på samme tid bange for kornmangel, og foreslog d. 3. dec. 1800 , at byen fik del i magasinkornet, for at sikre de trængende mod den truende hungersnød. Magistraten fandt forslaget berettiget $\mathrm{g}$ bad om at få overladt 371 td. Men rentekammeret afviste ideen. ${ }^{146}$

Eksemplerne viser, hvor trykkende mangelen og de høje priser føltes, og afslører samtidig, at udførselsforbudet af 1 . aug. $1800 \mathrm{ikke}$ for alvor havde hjulpet bybefolkningen. Så alvorlig fandt statholderen situationen, at han $\mathrm{i}$ dec. 1800 foreslog, at hver plov jord mod betaling skulle pålægges at levere 1-2 td. rug, som mod betaling skulle overlades byerne til salg blandt småfolk. ${ }^{147}$

Gennem forår og sommer 1801 vedblev korn og smør at være mangelvarer. Stadig blev producenter og købmænd anklaget for ulovligt opkøb og for at holde varerne tilbage i tro på snarlig og lukrativ tilladelse til udførsel. Enkelte gange fik de utilfredse forbrugere deres vilje. I Åbenrå hed det sig i august 1801, at købmand Jacob Peter Holm købte smør op for at udføre det, og den menige mand så heri årsagen til de høje priser. Byfogeden lånte øre til anklagerne og konfiskerede "på nogle gamle koners råd" smør i Holms hus. 
Købmandens klage over beslaglæggelsen nyttede intet, da kongen senere på året godkendte det skete. ${ }^{148}$

Men så kom høsten. Den blev overordentlig frugtbar. Nu faldt priserne, også fordi der atter var fred $i$ udlandet og det blev muligt at få tilførsler fra Østersøen. Derfor kunne regeringen d. 7. april 1802 tillade eksporten. Først nu kom frihandelstanken atter til udfoldelse.

Der kan herefter konkluderes, at 1799-1801 var præget af næsten uafbrudte "næringssorger for den menige forbruger. Mangelen og de høje priser skyldtes i nogen grad gentagne dårlige høstudbytter. Men dette kan ikke alene forklare vanskelighederne. Af lige så afgørende betydning har det varet, at tilførslerne fra udlandet standsede, og at opkøb og kraftig eksport var med til at tømme hjemmemarkedet og presse priserne op. Også i disse år rørte befolkningen på sig i utilfredshed, og mange lokale øvrigheder måtte foranstalte ekstraordinær hjælp. Regeringen var på sin side nødsaget til at forbyde eksporten og således støtte forbrugeren mod de handlendes profitbegær.

\section{$1845-1847$}

Fra århundredskiftet vil vi springe frem til 1845. Vi vil forbigå dyrtidsproblemerne i 1805, under Napoleonskrigen og i årene op til 1818, ligesom uåret 1819 og hungerårene omkring 1830. Sidstnævnte er behandlet $i$ Sønderjysk Månedsskrift 1980. Men der er grund til at fremhæve, at frihandelstanker og liberale økonomiske ideer i denne periode vandt indpas $\mathrm{i}$ borgerskab og regeringskredse, så de i perioden $1830-48$ var blevet den herskende opfattelse. Uvilje mod regeringsindgreb og ønsket om at afhjælpe de værste problemer ad frivillighedens vej var nu god latin.

Da den sidste alvorlige hungerkrise indtraf i 1845-47, blev der derfor lejlighed til at demonstrere, hvordan man tacklede problemerne i en tid, hvor frihandel var et uantastet dogme.

I flere årtier havde kartofler udgjort en central del af menigmands ernæring, og krisen begyndte med en alvorlig kartoffelsygdom i 1845 og 1846. Kornhøsten i 1845 var rimelig god, men kartoffelmisvæksten pressede priserne op. Rentekammeret sendte en udstykningskommissær Prehn rundt $\mathrm{i}$ Sønderjylland for at undersøge sygdommens omfang, og generaltoldkammeret og kommercekollegiet indhentede de lokale øvrigheders udtalelse om de fornødne forholdsregler. ${ }^{149}$

Stemningen talte mod eksportforbud, og der blev ikke grebet ind. Bladet Dannevirke priste regeringen for derved at tillade landbruget en kærkommen gevinst og mente, at også de fattige havde gavn af de høje priser. For jo højere 
priser jo mere "gives der for den arbejdende klasse at fortjene «. Alligevel kunne man nære frygt for de ubemidledes ernæring, men dette søgte man at klare ved rundt om i sognene at opfordre bønderne til at holde korn tilbage, som i påkommende tilfælde kunne sælges til moderat pris.

Det følgende år forværredes tilstanden. Atter ødelagdes kartoffelhøsten af sygdom, og ovenikøbet blev høsten temmelig ringe. Priserne steg. Noget måtte gøres, og som tidligere i denne liberalismens tid valgte regeringen at appellere til det frivillige initiativ. D. 20. okt. 1846 udtalte regeringen på Gottorp: "Efter tidligere erfaringer er aftaler mellem private, som påtager sig opkøb af korn og andre frugter, for at sælge dem for moderat pris til private, særlig virksomme «. Derfor opfordrede den øvrighederne til at virke for dannelse af sådanne foreninger. ${ }^{150}$ Yderligere ophævedes indførselstolden for kornvarer d. 9. dec. Alligevel steg priserne. I Flensborg kostede rug i sept. 14 mk., i dec. $17 \mathrm{mk}$., og talrige steder måtte frivillige foreninger $\mathrm{i}$ den hårde vinter sørge for billigt korn, således i Flensborg. ${ }^{151}$ I mange sogne blev der ligeledes foranstaltet frivillige subskriptioner af korn blandt bønderne.

Langt værre blev det $\mathrm{i}$ foråret 1847 indtil april og maj, da krisen kulminerede. Priserne tordnede i vejret. Chresten Chrestensen Kaad i Majbøl skrev $\mathrm{i}$ januar 1847: „Vinteren er overmåde simpel, ingen betydelig sne, fryser

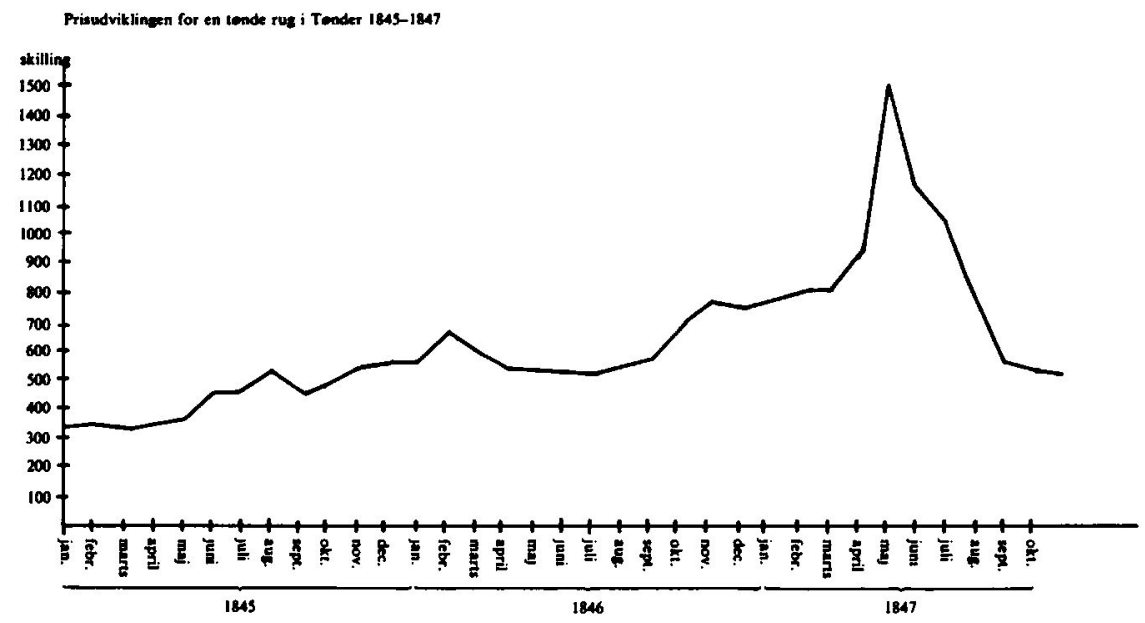

Prisudviklingen for en tonde rug $i$ Tonder 1845-47. Krisen toppede ifordr og forsommer 1847, da de hjemlige lagre var tomt, bl.a. pả grund af en kraftig eksport. Med indfersel fra Østerselandene i juni faldt priserne straks, og den gode hest i 1847 gjorde en ende pả krisen. Kilde: LA Ab Tender byarkiv, relationsprotokoller. 
kun lidet og tiden går således godt hen for de fattige i den overmåde dyre tid, thi kornpriserne er høje. Rugen koster $16 \mathrm{mk} .8 \mathrm{skl}$... « I maj var rugprisen sammesteds $27 \mathrm{mk} .{ }^{86}$ I Flensborg steg en tønde rug fra $14 \mathrm{mk}$. i sept. 1846 til ca. 22 mk. i juni 1847, da kulminationen var overstået. ${ }^{151}$ På Løjt var prisen først på året $184613 \mathrm{mk}$., men i april 1847 lå den på $26 \mathrm{mk}^{152}$

Nøden og kornmangelen blev grænseløs. Korn blev eksporteret $i$ betydeligt omfang, men frihandelen blev alligevel fastholdt som et ukrænkeligt princip. Regeringen nøjedes med at fritage kornimporten for alle afgifter, men måtte erkende, at dette ikke var nok, da »den arbejdende klasse for øjeblikket $\mathrm{i}$ almindelighed befinde sig $i$ en mere eller mindre trængende stilling “. For at hjælpe denne befolkningsgruppe valgte man ved resolution af 14. april 1847 at eftergive de mest trængende 47.000 rbdlr. i ekstraskatten. ${ }^{153}$ Skattelettelsen skulle fordeles på de mest trængende blandt dem, som ikke nød fast understøttelse af fattigkasserne.

Hvor frygtsomt man i øvrigt holdt sig til frivillige initiativer viser et eksempel fra kongeriget. Et amtsråd havde under hensyntagen til den kraftige udførsel, mangel og dyrtid foreslået, at sogneforstanderskaberne blev opfordret til ved ligning på sogneboerne at sikre det nødvendige kornforråd. Hertil svarede kancelliet, at lovgrundlaget for en sådan ligning manglede, "hvorimod det måtte overlades til den private velgørenhed at tilvejebringe « de nødvendige forsyninger. De »frivillige sammenskud« var at foretrække. ${ }^{154}$

Den almindelige opinion var ligeledes modstander af indgreb - trods den åbenbare nød. D. 10. april refererede Dannevirke således klager over, at whandelsstanden opkøber og udfører landets kornforråd så nær, at der snart vil indtræde almindelig mangel . Mange mente, at det var en stor synd, at udførslen og prisstigningen ikke blev hindret af regeringen, »der med ligegyldighed ser på en sådan dyrtid og ikke griber til det rette middel til at afhjælpe den fattige og mellemklassens nød«. Det var den voldsomme udførsel, som trods kornrigdom skabte nøden. Over for disse traditionelle betragtninger, som vi i det foregående har fulgt gennem et helt århundrede, og som tidligere havde fundet gehør hos regeringen, havde Dannevirke kun foragt til overs. At hindre eksport var vold mod ejendomsretten, var konfiskation af en velfortjent gevinst. Udførslen var en livsåre, som øgede landets velstand og var der optræk til mangel i en egn, kunne man med fordel hente billigere korn fra $\varnothing$ stersøen. Den frie uhindrede handel ville altid ordre alt til det bedste. En moralsk lære kunne man også drage: »Bondestandens stigende velvære er, trods de højeste brødpriser, en borgen for, at ingen som ved dygtighed gider gjort sig uundværlig eller idetmindste aldeles brugbar i samfundet, behøver at lide sult «. Det var bondens eksport, som holdt landet 
oppe, og kun ladhed og sorgløshed, som fik en bestemt folkeklasse til at kræve forstyrrende indgreb i landets livsåre, produktudførslen. ${ }^{155}$

Dannevirke udtrykker her den nye liberalistiske ideologi, den sejrende tankegang over for traditionel reguleringspolitik, og udtrykker også modsætningen mellem producent- og forbrugerinteresser.

Samme modsætning mellem styring og liberalisme kom lysende klart frem i en sag fra juni 1847 , da krisen netop var overvundet. En købmand Jens Petersen fra Flensborg havde købt en gård ved Hejls, hvorfra han drev storopkøb og udskibning af korn. Hans handel gav egnen mulighed for en bekvem og givtig afsætning af produkterne, men fik også priserne til at stige. $\mathrm{Nu}$ bad Petersen om formel tilladelse til at drive korn- $\mathrm{g}$ træhandel en gros $\mathrm{i}$ Hejlsminde. Sagen gik til udtalelse hos forskellige myndigheder. Brødremenigheden i Christiansfeld talte mod projektet, idet der var afsætningsmuligheder nok i Haderslev, Kolding og Christiansfeld, og virksomheden skadede Christiansfeld. Men især var den øgede afsætning til skade for de fattige på grund af prisstigningen. Noget lignende blev anført af Tyrstrup herredsfogderi, Haderslev amt og by. Sidstnævnte fandt, at opkøbene var "en slags grusomhed " mod småfolk på landet og mod byerne. Loven forbød imidlertid ikke Petersens virksomhed, idet kornhandel var helt fri. Over for de lokale øvrigheders "ga mmeldags « opfattelse talte regeringen på Gottorp frihedens sag. De gamle lovregler om handel på landet var ikke længere gyldige, og til brødremenighedens betragtninger udtalte den: "Når en lettelse $i$ afsætningen af landets produkter, midlerne til en fri konkurrence i opkøb og salg, fremstilles som skadelige for det almene, så bør der ikke tages hensyn til sådanne mod enhver sund handelspolitik stridende opfattelser «. Resultatet blev da også, at Petersen fik sin koncession. ${ }^{156}$

Regeringen gik altså på dette tidspunkt ind for storhandelens anskuelser, og alt imens havde opkøb og udskibning i foråret 1847 skabt en hidtil uset priseksplosion. I vinter og forår var Tyskland blevet ganske blottet for korn, og i april 1847 opkøbte Hamborg derfor korn i Danmark til skyhøje priser. D. 7. maj måtte Dannevirke indrømme, at nu var landets sidste kornreserver på vej bort "ført af hvide sejl over bølgernes rygge«. Priserne var blevet "unaturlige", havde hævet sig over "rimeligheden". Rundt om i kongeriget kom det til uroligheder på grund af brødmangel, og først i maj fandt kongen det nødvendigt at give byerne en kontantstøtte til opkøb af levnedsmidler i de næste fem måneder. ${ }^{157}$

I Flensborg købte byen kartofler og rug til de fattige, som ikke fik understøttelse, og private hjælpeforeninger sørgede for mel, kartofler og tørv, dels gratis dels billigt til de fattige. Dog udtalte Flensborg magistrat sig mod indgreb i den fri handel. ${ }^{157}$ I Abenrå sørgede en understøttelseskommis- 
sion bestående af borgmester Schow, senator Jørgen Bruhn og tre deputerede for, at ubemidlede kunne hente korn hos købmændene til nedsat pris. ${ }^{158}$ Desuden blev det for at hindre opkøb og eksport forbudt at købe korn op på landet uden om markedet. ${ }^{159}$ I Haderslev synes mangelen ikke at have været så slem, idet bonderne hele tiden havde indfundet sig på torvet med deres varer. ${ }^{160}$ I Løgumkloster arbejdede en kommission i vinteren 1846/47 og i foråret 1847 med fordeling af frivillige gaver, ${ }^{161}$ men hverken dette eller kongens skattelettelse kunne hindre, at småfolk blev sat tilbage, fordi de var nødt til at sælge indbo og optage lån, og dermed blev berøvet alle fremtidige hjælpekilder. I Løjt blev bønderne i vinteren 1845/46, da prisen for en tønde rug var $13 \mathrm{mk}$. opfordret til at levere rug til de fattige til $10 \mathrm{mk}$. pr. td. og den indsamlede mængde korn viste sig mere end tilstrækkelig. Fra efteråret 1846 til april 1847, da priserne fortsatte opad, tegnede bønderne sig atter for at levere rug til nedsat pris, men nu forslog kornet ikke, og sognet måtte selv købe korn. Hele 100 personer benyttede sig af hjælpen. Derefter blev mangelen værre og værre, og først $i$ april 1847 kunne man end ikke få det korn som var bestilt i Åbenrả. ${ }^{162}$ I sin nød sendte man da en mand til Flensborg for at få korn.

Situationen var desperat, men så ved midten af juni 1847 lettede det. Kornskibe fra Rusland ankom til Flensborg. Blandt de heldige købmænd var E. G. Boysen i Flensborg. Han havde om vinteren købt rug i Petersborg til $14 \mathrm{mk}$. $\mathrm{Nu}$ ankom ladningen, og $1000 \mathrm{td}$. deraf kunne han sælge til 20-22 mk., resten på $500 \mathrm{td}$. købte byen for $18 \mathrm{mk}$. pr. td. til fordeling blandt fattige. "Ein schöner Avance“, noterede Boysen i sin regnskabsbog. ${ }^{151}$

Med de udenlandske forsyninger i midten af juni 1847 lettede mangelen lidt efter lidt, omend priserne kun faldt langsomt. I Løjt måtte man således indsamle $306 \mathrm{mk}$. $3 \mathrm{skl}$, som blev brugt til at nedsætte rugprisen til $20 \mathrm{mk}$. pr. tønde indtil høsten. ${ }^{162}$ Men endelig kom høsten 1847, og den blev en velsignelse. Sjældent var den så rig, og dermed var den alvorligste nød overstået, og priserne faldt hurtigt.

Nøden havde man denne gang - tro mod de liberalistiske tanker - søgt at klare uden indgreb. Frivillige initiativer og skattelettelser var de anerkendte midler. Derfor kunne Kollegialtidende i sin bekendtgørelse om høstgudstjeneste udtale: "Vi vil, at undersåtterne tilkendegives Vor tilfredshed med den omsorg, der på en så agtværdig måde er vist de trængende under dyrtiden og med det under samme i det hele udviste rosværdige forhold, hvormed de har svaret til vore forventninger. « $^{163}$

Skal man sammenfatte oplysningerne om kriseåret 1847 , må det konstateres, at den helt usædvanlige prisstigning i første halvdel af $1847 \mathrm{og}$ den deraf følgende mangel og nød næppe kan forklares blot med den dårlige høst $\mathrm{i}$ 
1846. Mangel i udlandet og kraftig efterspørgsel øgede derimod presset på hjemmemarkedet. Markedet blev grebet af spekulation, og frihandelsideologien gav krisen frit løb hen mod kulminationen i april-maj måned. Udenrigshandelen var altså en afgørende faktor for den hjemlige udvikling. Uden frihandelsideologien og den voldsomme kornspekulation og eksport havde krisen næppe toppet, som den gjorde.

Spekulanterne, ikke mindst i Hamborg, var altså med til at skabe krisen. Men ikke alle kom godt fra det. Da prisen faldt efter høsten i 1847 , skete det brat. På Københavns børs faldt rugprisen således fra $28 \mathrm{kr}$. pr. td. i maj 1847 til $10 \mathrm{kr}$. pr. td. et halvt år efter. Et så enormt fald ramte kornhandlerne hårdt, og fallitter bredte sig i Hamborg, der i stor udstrækning havde deltaget $\mathrm{i}$ spekulationerne. ${ }^{164}$ Alt har sin pris!

\section{Slutord}

Årene 1845-47 danner epoke. Også senere, således allerede i 1853, træffer man dyrtid som følge af spekulationsopkøb og krigsuro. Men egentlige levnedsmiddel- og mangelkriser blev sjældnere. Et forbedret høstudbytte og bedre transportmuligheder, herunder oversøisk import, fik i den følgende periode en stærkt regulerende virkning på levnedsmiddelpriserne, så man undgik de mest katastrofale prissvingninger.

Derfor kan vi nu sammenfattende se tilbage over det forudgånde halvandet hundrede år. Til enhver tid var høstudbyttet afgørende for prisudviklingen, og kriseårene 1698-99, 1709-10, 1770-72, 1799-1800, 1829-30 og 1845-47 havde alle udgangspunkt $i$ dårlige høstudbytter. Men høstudbyttet giver alligevel ikke en udtømmende forklaring.

Sønderjylland var led $i$ en større sammenhæng, påvirket af høstudbyttet, krigsforhold og efterspørgsel i udlandet. I 1740, 1790 og 1795, delvis også i 1847, synes en altfor kraftig efterspørgsel fra udlandet, hvor misvækst, mangel og dyrtid rådede, at give forklaringen på problemerne her hjemme. Og selv i år, hvor høsten her hjemme klart svigtede, blev vanskelighederne øget af, at tilførslerne fra udlandet standsede, samtidig med at eksporten blev a nimeret af endnu højere priser på eksport - end på hjemmemarkedet. Det er endelig påfaldende, at flere af kornkriserne falder sammen med opkøb i forbindelse med krige eller krigsforberedelser. Det gælder 1740, 1756-58, 1762 og i 1790 'erne.

Udenrigshandelen rummer altså et væsentligt element til forståelse af kriseårenes forløb. Kornhandlerne blev derved nøglefigurer i dramaet. De søgte til enhver tid at skaffe sig den mest givtige afsætning, og de veg ikke tilbage for at blotte hjemmemarkedet for varer, enten ved oplagring eller 
eksport. Deres interesser faldt et langt stykke sammen med bøndernes, for hvem det gjaldt om at sælge produkterne dyrest muligt.

Modsatte interesser blev fremført af forbrugerne, især byerne, som kom i klemme under de høje priser. Byernes angreb på "kornågeren m mundede derfor oftest ud i krav om en kraftig regulering af handelen, eksportstop og hensyntagen til hjemmemarkedet. Forbrugernes interesser var vel altid de samme, men deres protest skiftede karakter. Indtil 1770'erne hører vi intet om, at de selv $i$ handling søgte at påvirke udviklingen. Tilsyneladende fandt de sig roligt i de ydre omstæendigheder. Men fra 1780'erne făr de selv stemme. Da hører vi gentagne gange om uroligheder, udsprunget af frygt for det daglige brød. Almuen tog nu sig selv til rette. Disse år danner derfor epoke i udviklingen hen mod et "demokratisk“ samfund.

Regeringen var $\mathrm{i}$ en vanskelig stilling over for kornproblemerne. Den skulle på én gang sørge for rimelige vilkår for byerhvervene og forbrugerne her. Men den skulle også skaffe gode eksportindtægter og øge bøndernes mulighed for takket være gode priser at betale skatterne. Op til 1770'erne tog regeringen hyppigst ud fra gammel tradition de ubemidlede undersåtters parti, og indførte derfor eksportstop og markedsregulering. Derefter vandt frihandelstanker frem, og man forsøgte at fastholde en fri eksport samtidig med, at man søgte at afbøde dens uheldige virkninger ved regler om oplagring af et vist forråd i magasinerne. I 1790'erne måtte man, vel af frygt for uro i befolkningen, trods alle frihandelstanker, indføre en stærk regulering. Men det var kun et skridt på vejen mod den endelige liberalisering. I 1830'erne og 1840 'erne fulgte man de løse tøjlers politik og prøvede at afbøde følgevirkningerne ved frivillige initiativer.

\section{NOTER OG HENVISNINGER}

1. Dansk socialhistorie bd. 7, 1980, s. 217.

2. Dansk socialhistorie bd. 4, 1979, s. 206 .

Aubin u. Zorn: Handbuch der deutschen Wirtschafts- und Sozialgeschichte bd. 1, 1971, s. 525.

3. Aubin u. Zorn op. cit. s. 406. Fontana Economic History of Europe bd. 3, 1973, s. 89 og 177 og 453rf.

4. Milward and Saul: The Economic Development of Continental Europe, 1973, s. 42. Aubin u. Zorn, op. cit. s. 41 1, 630, 405ff. Fontana Economic History of Europe bd. 3, 1973, s. 86.

5. L. Andresen: Geschichte der Stadt Tondern bis zum dreissigjährigen Krieg, 1939, s. 198. De Hansborgske Registranter I, 1943, s. 202, 230. H. V. Gregersen: Toldsted ved Hærvejen, 1978 , s. $78 f f$.

6. LA Sch Abt 7 nr. 3296.

7. Acta Borussica bd. 1, 1896, s. 106, 428, 433. bd. II, s. $132 \mathrm{ff}$.

8. LA Sch Abt 7 nr. 3300. 
9. LA Ab trykte frdn. $169817 / 9$.

10. RA Rtk. $2212.12169817 / 9$.

11. Had. rådstue XIX E 2.

12. Flensborg byark. 303,1 .

13. RA Rtk. ty. afd. assignationskontor brevbog $16988 / 10$.

14. ibid. brevbog $16993 / 1$.

15. Senderborg bys historie bd. 1, 1960, s. 117.

16. RA Rtk. $2212.12169815 / 11$.

17. Schleswig Holsteinische Provinzialberichte 1789, 3. hft. s. 224 f.

18. Flensborg byarkiv 303,1 $16999 / 9$.

19. LA Sch Abt $7 \mathrm{nr} .3300,1699$ okt.

20. F. V. Mansa: Bidrag til Folkesygdommenes og Sundhedspleiens Historie i Danmark, 1873, s. 498.

21. RA Rtk. $2212.13169919 / 8$ og 19/9, jvfr. QuFGSH bd. 26 s. 96.

22. Flensborg byarkiv nr. 303,1 .

23. RA Rtk. $2212.14169910 / 10$.

24. RA Rtk. 2212.121698 4/10.

25. J. A. Fridericia: Det syttende og attende aarhundredes historie, 3. udg., 1966, s. 292. Verdenshistoriens Hvornår skete det 2, 1960, s. 483. Acta Borussica bd. 2, 1901, s. 171ff. Milward and Saul: The Economic Development of continental Europe, 1973 s. 42. QuFGSH bd. 35 s. 68 note 255.

26. Edv. Holm: Danmark-Norges indre historie 1660-1720, bd. 2, 1886, s. 275 f.

27. Sønderborg bys historie bd. 1, 1960, s. 131 og LA Åb Sønderborg byark, nr. 1251708 $24 / 12$.

28. LA $\AA$ b $\AA$ b byark. nr. 80 .

29. Qu FGSH bd. 26 s. 96 og bd. 35 s. 62.

30. LA Åb Åb byark. 77 I og Tønder byark. nr. 126.

31. LA Åb Åb byark. repertorium 1697-1768.

32. Morten Kamphövener: Møllens røst, 1944, s. 46.

33. RA R tk. ty afd. ekspeditionsprot. 1709 14/10.

34. LA Åb Åstrup kirkebog.

35. Edv. Holm: Danmark-Norges historie 1720-1814, bd. 2, 1894, s. 123-143.

36. RA Komm. koll. ordre og missiveprot. 1739-41, 1740 15/3. LA Åb Åb byark. 77 II. Tønder byark. nr. 353. Åb amtsarkiv afl. fra Kiel C II $1 \mathrm{nr}$. 113. Had rådstue relationsprot. 1740 14/3. Jvfr. QuFGSH bd. 26 s. 97 ff.

37. Flensborg byark nr. 303,1.

38. Had. rådstue relationsprot. $174014 / 3$.

39. RA komm. koll. ordre- og missiveprot. 1739-41, 1740 3/5. LA Åb Åb byark. 77 II 1740 $3 / 5$.

40. Flensborg byark. 303,2.

41. Jens Holmgaard i Historie, ny rk. XII 1977-78 s. 345.

42. LA Åb Løgumkloster amtsarkiv afl. fra Kiel C V 1 nr. 59.

43. LA Åb Åb byark. 155.1, 1740 31/5. Tønder byark. 353 og relationsprot. $17401 / 6$.

44. Jens Holmgaard i Historie Ny rk. XII 1977-78 s. 342.

45. LA Åb Ab amt afl. fra Kiel C II 1 nr. 1131740 7/6.

46. Had. rådstue relationsprot. $174015 / 6$ og 8/6. LA Åb Tønder byark. relationsprot. 1740 $10 / 6$ og $21 / 6$.

47. LA Áb Legumkloster amtsarkiv afl. fra Kiel C V 1 nr. 59, 1740 20/6.

48. LA $\AA$ b $\AA b$ amt relationsprot. 1740 22/6. RA Statholderen 16,5 .

49. LA $\AA \mathrm{b} \AA \mathrm{b} b$ amt Verfügungsprot. $1738-40,1740$ 23/6. Nordborg amt aft. fra Kiel C III 5,483 . 
50. LA Åb H. Lausten-Thomsens privatark. A. Petersen Sandemand, optegnelser 1740.

51. RA Komm. koll. 215. Ordre- og missiveprot. 1739-41, 1740 21/6 (om Had.). LA Åb Åb amt afl. fra Kiel C II $1 \mathrm{nr}$. 113, 1740 28/6. Flensborg byark. 303,2.

52. LA Åb Legumkloster amt afl. fra Kiel C V 1 nr. 59, 1740 23/9.

53. Had. rådstue relationsprot. $174027 / 10$.

54. Flensborg byark. 303,2 $174022 / 10$.

55. Til en lign. vurdering er Jens Holmgaard nảet i Historie Ny rk. XII, 1977-78 s. 358f.

56. LA Sch Abt. 66 nr. 4939.

57. Flensborg byark. $845,175618 / 6$ og $20 / 6$ samt 303,2 .

58. Had. rådstue relationsprot. $175618 / 6,20 / 6$ og $3 / 7$.

59. LA Åb Tønder byark relationsprot. $17569 / 7$.

60. Flensborg byark. $845175620 / 6$.

61. ibid. $17561 / 9$ og $9 / 9$.

62. LA Åb Tønder byark. relationsprot. 1756 okt.

63. RA Komm. koll. ty, sekr. jr. 1756 nr. 234.

64. LA Åb Sønderborg byark. 125, 1756 15/10.

65. Trykte plakater og frdn.

66. Had. rådstue relationsprot. $175630 / 10$ og LA Åb Tender byark. relationsprot. 1757 23/6.

67. LA Åb Sønderborg byark. $125,175726 / 1$.

68. RA Rtk. ty. assignationskontor jr. nr. C 1589, 1757 13/6.

69. LA Åb Tønder byark. relationsprot. 1758 25/4. Åb byark. 77 Il 1758 20/5.

70. LA Ab Tonder byark. relationsprot. $17613 / 12$.

71. Had. rådstue XIX E $2176230 / 3$.

72. LA Åb Áb amt afl. fra Kiel C II $1 \mathrm{nr} .113,17627 / 4$.

73. Flensborg byark. $845176223 / 11$.

74. Aubin u. Zorn op cit. s. $524 \mathrm{og}$ 630. The Fontana Economic History of Europe bd. 3, 1973, s. 86. Wilh. Abel: Agrarkrisen u. Agrarkonjunkturen, 1966, s. 24. Wilh. Abel: Massenarmut und Hungerkrisen im vorindustriellen Deutschland, Göttingen 1972, s. 46ff. Anneliese Staff: Die Hungerkrise 1771-1773 in Deutschland im zeitgenössischen Urteil, Staatsexamensarbeit Kiel 1980.

75. Edv. Holm: Danmark-Norges Historie 1720-1814, IV 2, 1902, s. 64ff. LA Åb degn i Østerløgum Jørgen Hansens optegnelser.

76. Aage Rasch: Dansk toldpolitik 1760-1797, 1955, s. 120 og 134.

77. LA Áb Åb amt afl. fra Kiel C II $1 \mathrm{nr} .113,1770$ 6/10.

78. LA Ab Tønder byark. relationsprot. $177024 / 10$.

79. LA Åb Åb byark. 77 II, $17704 / 11$.

80. Had. rådstue XIX E 2, 1770 10/11. LA Åb Tønder byark. relationsprot. 1770 9/11.

81. LA Åb Løgumkloster amt C V $1 \mathrm{nr} .59,1770$ 10/11.

82. LA Áb Sønderborg byark. 125, $177011 / 11$.

83. RA Rtk. ty. forest. $1771 / 15$.

84. LA Áb Tønder byark. relationsprot. $177129 / 3$.

85. RA Rtk. ty. forest. $1771 / 63$.

86. LA Åb privatark. 429: Chr. Chrestensen Kaads dagbog.

87. LA Áb Åb amt afl. fra Kiel C II $1 \mathrm{nr} .113,177113 / 11$.

88. ibid. $177117 / 10$.

89. Flensborg byark. 845, $177125 / 12$.

90. LA Åb Åb byark. 77 II, $17716 / 11$.

91. RA Rtk. ty. forest. $1771 / 161$ og $1772 / 69$.

92. Flensborg byark. 303,3, $177230 / 9$.

93. RA generaltoldkam. forest. ty. 1780/46. Komm. koll. ty. sekr. jr. 1781/13-14 og 36 .

94. Flensborg byark. 303,4 178130/1. 
95. Joh. Hvidtfeldt i SJy Årb 1945 s. 130 fog LA Áb Åb amt C II 1 nr. 163, 1782 28/9.

96. RA Rtk. ty. forest. $1784 / 167$ og 170 og som note 86 .

97. LA Åb Tønder byark. nr. 93.

98. LA Åb Åb byark. repertorium 1769-1800, $1784 \mathrm{nr} .1$.

99. RA Rtk. ty. forest. 1784/167, $178410 / 8$.

100. LA Åb Tønder byark. relationsprot. $178625 / 4$.

101. LA Sch Abt. 66 nr. $2120,17877 / 9$ og 8/9.

102. LA Åb Svenstrup kirkekrønike s. 240.

103. Acta Borussica I, 1896, s. 128 og IV 1931, s. $173 f$.

104. LA Ab Schackenborg godsarkiv Breve 1783-90, 1790 22/1.

105. Flensborg byark. 303,4 $17897 / 11$.

106. Aage Rasch: Dansk toldpolitik 1760-1797, 1955, s. 243.

107. LA Sch Abt $66 \mathrm{nr} .21201787$ 18/9 og 26/9.

108. LA Åb Áb byark. 77 II 1789 4/11 og 12/12.

109. Johan Hvidtfeldt i SJy Årb 1945 s. $133 f f$ og LA Åb Tønder byark. indk. breve 1790 22/9. Ludwig Andresen i Beiträge zur neueren Geschichte der Stadt Tondern, 1943, s. $111 \mathrm{ff}$.

110. LA Ab Sønderborg byark. 125, 1790 19/2.

111. LA Åb Åb byark. 77 II $179015 / 2$ og RA Rtk. ty. forest. 1790/40.

112. LA Ab Åb amt afl. fra Kiel C II 1 nr. 164 og SJy Årb 1945 s. 137 og 1956 s. $209 f f$.

113. RA Rtk. ty. forest. $1790 / 40,17909 / 3$.

114. Ashton: Economic Fluctuations in England 1700-1800, s. 170. Acta Borussica bd. IV, 1931 , s. $183 \mathrm{ff}$.

115. RA Rtk. ty. forest. $1795 / 33$.

116. LA Ab Tønder byark. relationsprot. 1795 14/3.

117. SJy Årb 1945 s. 142.

118. LA Áb Tander byark. 141, $179513 / 6$.

119. LA Åb Tønder byark. 141, 1795 11/4, 30/5, 2/6. LA Sch Abt. 66 nr. 21201795 19/5.

120. RA generaltoldkam. ty. forest. 1795/13.

121. LA Áb Sønderborg amtsark. Kopibog over breve til overordnede 1795 1/8.

122. LA Åb Åb amt rtk.-sag 1795/250, $17953 / 6$.

123. Flensborg byark. 303,5 $17953 / 6$.

124. Flensborg byark. 845. RA Statholderen 7,2 og SJy Årb 1945 s. 142 f.

125. LA Áb Sønderborg byark. 125, 1795 22/6.

126. SJy Årb 1945 s. 143.

127. LA Áb Åb byark. 77 II.

128. LA Åb Tønder byark. relationsprot. 1795 20/6, 30/6, 6/7. Nr. 141 1795 6/7.

129. LA Åb Åb byark. 77 II $17953 / 7$.

130. RA Generaltoldkam. ty. forest. 1795/9.

131. LA Sch Abt $66 \mathrm{nr} .2120$.

132. RA Rtk. ty. forest. $1795 / 206$.

133. LA Åb Åb amt rtk-sag $1796 / 273$.

134. Flensborg byark. 845 .

135. f.eks. LA Åb privatark. 196, J. C. Friis' dagbog 1799.

136. LA Sch Abt. 66 nr. 1963, 1799 juni og sept.

137. En dansk bondeskippers historie, udg. af Historisk Samf. for Ribe amt 1977, s. 16.

138. LA Sch Abt $66 \mathrm{nr} .1963,1800 \mathrm{l} / 8$ og 30/7.

139. SJy Arb 1945 s. 145.

140. LA Åb Åb byark. 77 II.

141. Lars N. Henningsen: Fattigvæsenet i de sønderjyske købstæder 1736-1841, 1978 s. 135.

142. SJy Årb. 1945 s. $146 f$.

143. LA Sch Abt 66 nr. 1963. 
144. ibid. $180025 / 10$ og $28 / 10$.

145. Flensborg byark. $845180017 / 11$.

146. LA Åb Åb byark. 77 II.

147. LA Sch Abt 66 nr. $196318006 / 12$ og 20/12.

148. LA Åb Ảb byark. 81 .

149. Dannevirke. $184529 / 10,17 / 12$. Frdn. 1845 17/10. LA $\AA$ b Had. vesteramtsstue C I 1 nr. $470184518 / 10$.

150. Flensborg byark. 845 .

151. LA Åb privatarkiv acc. nr. 1141, 1846 dec. QuFGSH bd. $26 \mathrm{s.} 123$.

152. LA Åb Åb amtsark. 1848 XV 8, $18478 / 11$.

153. Dannevirke. $184728 / 4$ og LA Åb Åb amtsark. 1848 XI 141847 22/4.

154. Kollegialtid. 1847 s. 278.

155. Dannevirke. $184710 / 4$.

156. RA TKIA D 79 IV.

157. Flensborg byark. $845,18478 / 5$.

158. LA Åb Åb byark. $251 \mathrm{~b}$.

159. LA Áb Åb amtsark. 1847 III 46, 1847 12/5.

160. Dannevirke. 1847 16/6.

161. LA Åb Åb amtsark. 1848 XI 14, 1847 15/11.

162. LA Áb Åb amtsark. 1848 XV 8, $18478 / 11$.

163. Dannevirke. 1847 15/9.

164. V. Falbe-Hansen og Will. Scharling: Danmarks Statistik, bd. 3, 1878, s. 471. 